\title{
Acute Metabolic Acidosis Enhances Circulating Parathyroid Hormone, Which Contributes to the Renal Response against Acidosis in the Rat
}

\author{
Maurice Bichara, Odile Mercier, Pascale Borensztein, and Michel Paillard \\ Laboratoire de Physiologie et Endocrinologie Rénale, Université Pierre et Marie Curie, Hôpital Broussais; \\ and the Institut National de la Santé et de la Recherche Médicale CJF 88-07, Paris, France
}

\begin{abstract}
Acute PTH administration enhances final urine acidification in the rat. $\mathrm{HCl}$ was infused during $3 \mathrm{~h}$ in rats to determine the parathyroid and renal responses to acute metabolic acidosis. Serum immunoreactive PTH (iPTH) concentration signifcantly increased and nephrogenous adenosine $3^{\prime}, 5^{\prime}$-cyclic monophosphate tended to increase during $\mathrm{HCl}$ loading in intact and adrenalectomized (ADX) rats despite significant increments in plasma ionized calcium. Strong linear relationships existed between serum iPTH concentration and arterial bicarbonate or proton concentration $(P<0.0001)$. Serum iPTH concentration and NcAMP remained stable in intact time-control rats and decreased in $\mathrm{CaCl}_{2}$-infused, nonacidotic animals. Urinary acidification was markedly reduced in parathyroidectomized (PTX) as compared with intact rats during both basal and acidosis states; human PTH-(1-34) infusion in PTX rats restored in a dose-dependent manner the ability of the kidney to acidify the urine and excrete net acid. Acidosis-induced increase in urinary net acid excretion was observed in intact, PTX, and ADX, but not in ADX-thyroparathyroidectomized rats.
\end{abstract}

We conclude that (a) acute metabolic acidosis enhances circulating PTH activity, and (b) PTH markedly contributes to the renal response against acute metabolic acidosis by enhancing urinary acidification. (J. Clin. Invest. 1990. 86:430-443.) Key words: acidosis $\bullet$ PTH $\bullet$ urinary acid excretion

\section{Introduction}

Acute PTH administration was generally considered to increase urinary bicarbonate excretion secondary to inhibition of bicarbonate reabsorption in the proximal tubule. However, we have shown in rats (1) that the reported acute bicarbonaturic effect of PTH is secondary to an early transient increase in the GFR and thus bicarbonate-filtered load due to the vasodilatory properties of PTH. When this initial hemodynamic

Parts of this work were presented at the 21 st Annual Meeting of the American Society of Nephrology, San Antonio, TX, December 1988, and were published in abstract form (1989, Kidney Int. 35:389; and 1990, Kidney Int. 37:464).

Address correspondence and reprint requests to Dr. M. Bichara and Dr. M. Paillard, Laboratoire de Physiologie, Hôpital Broussais, 96 rue Didot, 75675 Paris cédex 14, France.

Received for publication 23 February 1989 and in revised form 6 March 1990.

J. Clin. Invest.

(C) The American Society for Clinical Investigation, Inc.

$0021-9738 / 90 / 08 / 430 / 14 \quad \$ 2.00$

Volume 86, August 1990, 430-443
PTH effect has vanished, i.e., after $\sim 1 \mathrm{~h}$ in the rat under the conditions of our study (1), the PTH-induced inhibition of bicarbonate and chloride in the proximal convoluted tubule is counterbalanced by an opposite effect in superficial Henle's loop so that the early distal delivery as.well as the excretion in final urine of these anions are unchanged during PTH infusion (1). In fact, we (1) and Bank and Aynedjian (2) have found that PTH administration dramatically enhances urinary acidification. PTH infusion in thyroparathyroidectomized (TPTX) ${ }^{1}$ rats was associated in the steady state with a decrease in urinary $\mathrm{pH}$ and an increase in urinary titratable acid, ${ }^{2}$ ammonium, and thus net acid excretion $(1,2)$. We have established that proton secretion in collecting ducts is stimulated during PTH infusion indirectly via the PTH-induced increase in urinary phosphate concentration $(1,3)$. In agreement with the acute PTH-induced stimulation of urine acidification just described, chronic PTH administration induces sustained metabolic alkalosis, at least in part of renal origin, in human (4), $\operatorname{dog}(5-7)$, and rat (8, and unpublished observations from our laboratory). Also, results of a recent study conducted.in our laboratory have demonstrated that chronic neutral phosphate administration in the rat, such as sodium and potassium salts, induces renal metabolic alkalosis secondary to sustained increased proton secretion in collecting ducts during up to $7 \mathrm{~d}$ (9). Finally, we have shown (10) that hypercalcemia per se increases the proximal and thus renal reabsorption of bicarbonate relative to chloride, which, if of sufficient magnitude and/or duration, would induce hyperbicarbonatemia and hypochloremia; this calcium effect on the proximal tubule may explain the chronic metabolic alkalosis, at least in part of renal origin, associated with hypercalcemia secondary to hyperparathyroidism or 1,25-dihydroxycholecalciferol administration $(6,8)$, or observed in patients with various neoplasms (11).

Thus PTH, urinary phosphate, and plasma calcium are major determinants of urinary acidification, a rise in each of these three factors being capable of enhancing net acid excretion. The aim of this study, therefore, was to determine whether acute acid loading acts on the circulating PTH concentration and whether PTH contributes to enhancement of net acid excretion during an acute metabolic acidosis. The results demonstrate for the first time in the rat that the serum

1. Abbreviations used in this paper: ADX, adrenalectomized; $\mathrm{PTTH}$ immunoreactive PTH; NcAMP, nephrogenous adenosine 3',5'-cyclic monophosphate; PTX, parathyroidectomized; TPTX, thyroparathyroidectomized.

2. Titratable acid represents the amount of acid that has titrated the urine buffers from the plasma $\mathrm{pH}$ to urine $\mathrm{pH}$. The term "ammonia" will refer to the sum of free-base ammonia $\left(\mathrm{NH}_{3}\right)$ and ammonium ion $\left(\mathrm{NH}_{4}^{+}\right)$. The term "net acid excretion" will refer to the sum of ammonium plus titratable acid minus bicarbonate in the urine. 
immunoreactive PTH (iPTH) concentration rises during $\mathrm{HCl}$ loading, and that PTH contributes to the renal response against acute metabolic acidosis by enhancing urinary ammonium, phosphate, and titratable acid, and thus net acid excretion.

\section{Methods}

\section{Animals}

59 male Sprague-Dawley rats weighing $305 \pm 4 \mathrm{~g}$ (mean \pm SE) were studied. They had been fed a standard commercial chow (A O4; UAR, Villemoisson-sur-Orge, France) containing $5.9 \mathrm{~g} / \mathrm{kg}$ phosphorus, 6.0 $\mathrm{g} / \mathrm{kg}$ calcium, and 2,020 IU/kg vitamin $D_{3}$ for at least $7 \mathrm{~d}$ before the study. Food was withheld $14-16 \mathrm{~h}$ before the experiment, but all animals had free access to water before anesthetization with Inactin (5ethyl-5-[1-methyl-propyl]-2-thiobarbituric acid), $100 \mathrm{mg} / \mathrm{kg}$ body wt. Each rat was studied initially during a 60 -min control period while receiving for $4 \mathrm{~h}$ an infusion of a $125-\mathrm{mM} \mathrm{NaCl}$ solution at $0.6 \mu \mathrm{l} / \mathrm{min}$ per $\mathrm{g}$ body $\mathrm{wt}$ and then during a 3-h experimental procedure. The experimental procedure was either an infusion of $\mathrm{HCl}(50 \mathrm{mM} \mathrm{HCl}$ replacing $50 \mathrm{mM} \mathrm{NaCl}$ in the infused solution, $30 \mathrm{nmol} \mathrm{H}^{+} /$min per $\mathrm{g}$ body $\mathrm{wt}$ ), an infusion of calcium chloride ( $7 \mathrm{nmol} / \mathrm{min}$ per $\mathrm{g}$ body $\mathrm{wt})$, or a time control. Thus, a slightly hypotonic fluid volume expansion was induced early during the preparatory surgery and maintained throughout the experiment in each rat to minimize possible variations in the extracellular fluid volume and circulating antidiuretic hormone activity, since we have shown that the latter are important determinants of tubule fluid and urine acidification $(12,13)$. Since the purpose of this study was to determine the place of PTH during acute metabolic acidosis, intact, parathyroidectomized (PTX), TPTX, and adrenalectomized (ADX) rats were studied. ADX rats were also studied because endogenous aldosterone and glucocorticosteroid secretion may be stimulated during acid loading (14-18) and because corticosteroid hormones are known to affect various renal functions, including urinary acidification and renal handling of ammonium, phosphate, and thus titratable acid. Varying circulating corticosteroid activities during acid loading could therefore cloud effects that may be due to PTH, as will be shown below. In addition, various groups of animals were necessary to study the parathyroid response to acid loading on the one hand and the renal response on the other hand, because a volume of blood sufficient for all measurements could not be sampled in the same animal.

\section{Serum iPTH and nephrogenous adenosine 3',5'-cyclic monophosphate measurements}

Group I: intact HCl-loaded rats. This group was composed of six rats that were studied twice: first during a 60 -min control period after $3 \mathrm{~h}$ of equilibration after surgery, and second during $3 \mathrm{~h}$ of $\mathrm{HCl}$ loading. Serum iPTH concentration and nephrogenous adenosine $3^{\prime}, 5^{\prime}$-cyclic monophosphate (NcAMP; excreted minus filtered cAMP) were determined in these rats.

Group II: ADX HCl-loaded rats. This group was composed of six rats that were studied as the rats of group I, except that they were ADX 3-4 $\mathrm{h}$ before the first control period. Adequacy of adrenalectomy was insured by an acceptance of the animals for the study only if the GFR was at least $20 \%$ below the normal value, which indicated a low circulating level of glucocorticosteroid hormones.

Group III: $\mathrm{CaCl}_{2}$-infused, nonacidotic rats. This group was composed of three intact rats that were studied during a first control period, and then during $3 \mathrm{~h}$ of $\mathrm{CaCl}_{2}$ infusion at $7 \mathrm{nmol} / \mathrm{min}$ per $\mathrm{g}$ body wt.

Group IV: time-control rats. This group was composed of three intact and three ADX rats in which the $125 \mathrm{mM} \mathrm{NaCl}$ solution infusion was maintained for $3 \mathrm{~h}$ after the initial control period to assess the spontaneous evolution with time of serum IPTH concentration, NcAMP, and urinary phosphate excretion.

\section{Renal response to acid loading}

In all the following groups that were designed to study the various components of urinary net acid excretion in response to acute metabolic acidosis, the animals were studied exactly as those of groups I and II, i.e., during $3 \mathrm{~h}$ of $\mathrm{HCl}$ loading after a first 60 -min control period.

STUDIES IN ADRENAL-INTACT ANIMALS

Group $V$, six intact rats.

Group VI: PTX rats. Six rats made up this group: four were PTX and two in which the parathyroid glands could not be easily localized were TPTX at least 3-4 $h$ before the first control period. Since there was no obvious difference in the various measured parameters between PTX and TPTX Idts, the results were pooled and the group will hereafter be referred to as the PTX group.

Group VII: PTX rats infused with human PTH-(1-34) [hPTH-(134)]. Eight rats were PTX early during the preparatory surgery and immediately infused with hPTH-(1-34) at constant rates, i.e., either 5-6 pg/min per $\mathrm{g}$ body wt (three rats, group VIIa) or $7-9 \mathrm{pg} / \mathrm{min}$ per $\mathrm{g}$ body wt (five rats, group VIIb) that produced, respectively, moderately low and high biological PTH activity as judged by the values of ionized calcium and inorganic phosphorus plasma concentration and urinary fractional excretion of inorganic phosphorus (see Results). Synthetic hPTH-(1-34) was chosen because rat PTH-(1-84) is not commercially available to our knowledge.

STUDIES IN ADX ANIMALS

As already mentioned, ADX rats were studied to assess the renal response to acid loading in the absence of varying corticosteroid circulating activities that could cloud effects that are due to PTH.

Group VIII: Six intact rats.

Group LX: Six ADX rats.

Group X: Six ADX-TPTX rats.

\section{Surgical and experimental procedures}

After anesthetization the rats were placed on a servo-regulated heated table that maintained their rectal temperature at $37^{\circ} \mathrm{C}$. All tissue incisions were made with an electric bistoury, coagulation was carefully produced with a cautery, and all exposed surfaces were covered with water-equilibrated paraffin oil. A PE-50 catheter (Biotrol, Paris, France) was inserted into the left femoral artery for continuous monitoring of blood pressure and for blood sampling; all blood samples were quantitatively replaced by whole blood obtained on the morning of study from another rat that was intact or TPTX the day before for PTX and TPTX rats. A solution containing $125 \mathrm{mM} \mathrm{NaCl}, 3 \mathrm{mM}$ $\mathrm{CaCl}_{2}$, and $1.5 \mathrm{mM} \mathrm{MgSO}_{4}$ was infused through PE-50 catheters into a femoral vein at $0.6 \mu \mathrm{l} / \mathrm{min}$ per $\mathrm{g}$ body $\mathrm{wt}$ and into both external jugular veins at $0.02 \mu \mathrm{l} / \mathrm{min}$ per g body wt. In the PTX rats of group VII, hPTH-(1-34) was added to one jugular infusion to achieve hPTH-(134) infusion rates of 5-6 or 7-9 pg/min per $\mathrm{g}$ body wt. A tracheostomy was performed and the rat was attached to a rodent respirator (Bioscience, Sheemess, Kent, UK) and ventilated for the duration of the study. The left ureter and the bladder were cannulated with PE-50 tubing through an abdominal approach. At the end of the surgery, an amount of $1.5 \%$ of plasma, obtained from another rat that was intact or TPTX the day before for PTX and TPTX rats, was administered and followed by a maintenance infusion of plasma at $0.05 \mu \mathrm{l} / \mathrm{min}$ per $\mathrm{g}$ body wt through a jugular vein (plasma repletion) as previously described (13). Through the other jugular vein, a priming dose of 12.5 $\mu \mathrm{Ci}$ of [methoxy ${ }^{3} \mathrm{H}$ ]inulin (New England Nuclear, Boston, MA) was given and followed by a sustaining infusion of $0.04 \mu \mathrm{Ci} / \mathrm{h}$ per $\mathrm{g}$ body wt.

After a 3-h equilibration period, a first 60 -min control period was performed. Thereafter, the solution infused through the femoral vein was replaced with a solution containing $50 \mathrm{mM} \mathrm{HCl}, 75 \mathrm{mM} \mathrm{NaCl}, 3$ $\mathrm{mM} \mathrm{CaCl}$, and $1.5 \mathrm{mM} \mathrm{MgSO}_{4}$ that was infused at the same rate of $0.6 \mu \mathrm{l} / \mathrm{min}$ per $\mathrm{g}$ body wt in $\mathrm{HCl}-$ loaded rats. In the rats of group III, $\mathrm{CaCl}_{2}$ was added to the $125 \mathrm{mM} \mathrm{NaCl}$ solution to achieve a $7 \mathrm{nmol} /$ min per $\mathrm{g}$ body wt calcium infusion rate. In time-control rats of group 
IV the $125 \mathrm{mM} \mathrm{NaCl}$ solution infusion was maintained. These experimental procedures lasted $3 \mathrm{~h}$. Each hour two or three timed urine collections were made under water-equilibrated paraffin oil and blood samples were obtained. An additional urine sample was collected during the last $10 \mathrm{~min}$ of each period for determination of urinary cAMP in some rats.

After the completion of the experiment, the left kidney was excised, blotted, and weighed.

\section{Analytical procedures}

Arterial and urinary $\mathrm{pH}$ and $\mathrm{PCO}_{2}$ were measured by a blood gas analyzer (model BMS3 MK2; Radiometer, Copenhagen, Denmark). Urine total $\mathrm{CO}_{2}$ (dissolved $\mathrm{CO}_{2}$ and $\mathrm{HCO}_{3}^{-}$) was determined by a carbon dioxide analyzer (model 965; Corning Glass Works, Corning, NY); the urinary bicarbonate concentration was calculated as the difference between the measured total $\mathrm{CO}_{2}$ and dissolved $\mathrm{CO}_{2}(0.031$ $\times \mathrm{PCO}_{2}$ ) concentrations. Ionized calcium concentration was determined in whole blood using a calcium ion-selective electrode (ICA1; Radiometer). The [methoxy- ${ }^{3} \mathrm{H}$ ] inulin radioactivity in plasma and urine was measured by scintillation counting (Betamatic; Kontron, Trappes, France). Titratable acid and ammonium urinary excretion rates were determined by automated titration methods. Net acid excretion rate was calculated as the sum of that of urinary ammonium and titratable acid minus bicarbonate. Serum iPTH concentration was measured with an intact $\mathbf{N H}_{2}$-terminal-specific PTH radioimmunoassay (Nichols Institute Diagnostics, San Juan Capistrano, CA). The intact $\mathrm{NH}_{2}$-terminal-specific PTH radioimmunoassay kit contains chicken anti-PTH serum directed against the 1-34 region of PTH, hPTH-(1-34) standards, goat anti-chicken gamma globulin precipitating antibody, and ${ }^{125} \mathrm{I}$-bovine PTH-(1-84) as tracer. The use of this kit for rat PTH measurement has already been validated by others (19). All measurements were made in duplicate on $300 \mu \mathrm{l}$ rat serum stored at $-20^{\circ} \mathrm{C}$ obtained from $600 \mu \mathrm{l}$ of blood collected into ice-chilled tubes. The concentration of cAMP in plasma and urine was measured by a cAMP ${ }^{125}$ I assay system kit (Amersham, Les Ulis, France) that is based on the competition between unlabeled cAMP and ${ }^{125}$ I-labeled cAMP for a limited number of binding sites on a cAMP-specific antibody. Separation of the antibody-bound fraction was effected by magnetic separation using a second antibody that is bound to magnetizable polymer particles (Amerlex-M-second antibody reagent). Each measurement was made in duplicate on $\mathbf{4 0} \mu \mathrm{l}$ of urine or plasma stored at $-20^{\circ} \mathrm{C}$; plasma samples were obtained after immediate centrifugation of $200 \mu \mathrm{l}$ of blood collected into ice-chilled tubes that contained a final concentration of $10 \mathrm{vol} \%$ of $7.5 \mathrm{mM}$ EDTA. Plasma and urine magnesium concentrations were measured by colorimetric determination (Mg-kit; Biomerieux, Paris, France). Urinary osmolality was determined by an osmometer (Fiske Osmometer, Uxbridge, MA). Other analytical procedures for determination of sodium, potassium, chloride, total calcium, inorganic phosphorus, and protein have previously been described in detail $(10,13)$.

\section{Calculations}

Whole kidney GFR was estimated from whole kidney [methoxy- ${ }^{3} \mathrm{H}$ ]inulin clearance. Urinary fractional excretion of a solute $x$ was calculated as (U/UF) $x /(\mathrm{U} / \mathrm{P})$ inulin in which $\mathrm{U}, \mathrm{UF}$, and $\mathrm{P}$ are urine, ultrafiltrate, and plasma concentrations, respectively. The ultrafiltrate concentrations of calcium, inorganic phosphorus, and magnesium were taken as $0.60,0.93$, and 0.80 times plasma water concentrations (20), respectively.

Only the results obtained from the left kidney, the ureter of which was cannulated, are presented. All absolute rates were factored by kidney weight to compensate for differences caused by animal size. Kidney weights ranged from 1.00 to $1.69 \mathrm{~g}$ with a mean value of $1.27 \pm 0.02 \mathrm{~g}$.

Results are expressed as means \pm SE. Statistical significance of differences within and between groups was assessed by one- or two-way analysis of variance as appropriate and the $t$ test only when the $F$ test was suitable.

\section{Results}

Effects of acid-loading on iPTH and NcAMP (groups I-IV) The results obtained in groups I-IV are summarized in Table I and in Figs. 1-3. As shown in Fig. 1, the $\mathrm{HCl}$ infusion induced a metabolic acidosis that was significantly more severe in ADX than in intact rats. After $3 \mathrm{~h}$ of acid loading, the arterial $\mathrm{pH}$ decreased to $7.27 \pm 0.02 \mathrm{pH}$ units in intact rats, and to $7.19 \pm 0.02 \mathrm{pH}$ units $(P<0.001)$ in ADX rats; also in the same time, the plasma bicarbonate concentration decreased to $14.2 \pm 1.1 \mathrm{mM}$ in intact rats, and to $11.2 \pm 1.4 \mathrm{mM}(P<0.05)$ in ADX rats. Arterial pH and plasma bicarbonate concentration remained stable in $\mathrm{CaCl}_{2}$-infused rats of group III (Fig. 1).

One of the striking findings of this study was that acute metabolic acidosis was associated with an increase in the serum iPTH concentration (Fig. 2) despite an increase in the arterial ionized calcium concentration (Fig. 1) in both intact and ADX animals. During acid loading, the serum iPTH concentration progressively increased from $21.8 \pm 3.7$ to $30.6 \pm 3.5$ $\mathrm{pg} / \mathrm{ml}(P<0.005)$ at the third hour in intact rats, and from $21.2 \pm 2.0$ to $39.1 \pm 4.4 \mathrm{pg} / \mathrm{ml}(P<0.001)$ in ADX rats. Note that the final value during acid loading for serum iPTH concentration was higher in ADX than in intact rats $(P<0.05)$, possibly because of a more severe metabolic acidosis in the former rats. Indeed, when serum iPTH concentration was plotted as a function of plasma bicarbonate or arterial $\mathrm{H}^{+}$ concentration, there was no significant difference in the significant relationships that were obtained in intact and ADX rats; the data obtained in both groups of animals were therefore pooled. As shown in Fig. 3, strong linear relationships existed between serum iPTH and plasma bicarbonate concentration $(r$ $=-0.63, P<0.0001)$ or arterial $\mathrm{H}^{+}$concentration $(r=0.52, P$ $<0.0001$ ); note that the correlation coefficient was higher with bicarbonate than with $\mathrm{H}^{+}$concentration (which was also the case when data in intact and ADX rats were taken separately). In the same time, the arterial ionized calcium concentration increased from $1.32 \pm 0.01$ to $1.35 \pm 0.01 \mathrm{mM}(P<0.005)$ in intact rats, and from $1.325 \pm 0.006$ to $1.38 \pm 0.02(P<0.01)$ in $\mathrm{ADX}$ rats. In $\mathrm{CaCl}_{2}$-infused, nonacidotic rats, the arterial ionized calcium concentration similarly increased from $1.32 \pm 0.02$ to $1.37 \pm 0.07 \mathrm{mM}(P<0.05)$ at the third hour of infusion, which, as expected, induced a significant decrease in the serum iPTH concentration from $22.7 \pm 0.4$ to $14.5 \pm 1.5$ $\mathrm{pg} / \mathrm{ml}(P<0.005)$. In addition, the plasma magnesium concentration remained stable in these animals (Fig. 1).

We determined NcAMP as an index of the biological activity of PTH on the kidney $(21,22)$. As shown in Fig. 2, NcAMP tended to increase, although not significantly, in intact and ADX $\mathrm{HCl}$-loaded rats in which the serum iPTH concentration increased; conversely, NcAMP tended to decrease in $\mathrm{CaCl}_{2-}$ infused, nonacidotic rats in which the serum iPTH concentration decreased. Thus, NcAMP was significantly higher in acidotic rats with high iPTH circulating activities than in $\mathrm{CaCl}_{2-}$ infused rats with low iPTH circulating activities $(P<0.025)$.

Finally, as shown in Table $I$, these various parameters were stable in intact time-control rats. In ADX time-control rats, an expected moderate metabolic acidosis extended with time, which was indeed associated with serum iPTH concentrations that tended to be higher than those in time-control intact rats. Note that urinary phosphate absolute and fractional excretion progressively decreased with time in time-control intact rats. 


\begin{tabular}{|c|c|c|c|c|c|}
\hline & \multicolumn{2}{|c|}{ Control period (h) } & \multicolumn{3}{|c|}{ Time-control (h) } \\
\hline & 0 & 1 & 1 & 2 & 3 \\
\hline \multicolumn{6}{|l|}{$\mathrm{Pi}, m M$} \\
\hline Intact & $2.4 \pm 0.2$ & $2.3 \pm 0.2$ & $2.2 \pm 0.3$ & $2.1 \pm 0.3$ & $2.1 \pm 0.3$ \\
\hline ADX & $2.6 \pm 0.1$ & $2.6 \pm 0.1^{*}$ & $2.6 \pm 0.1^{*}$ & $2.6 \pm 0.1^{*}$ & $2.5 \pm 0.1^{*}$ \\
\hline \multicolumn{6}{|c|}{ Magnesium, $m M$} \\
\hline Intact & $0.73 \pm 0.09$ & $0.72 \pm 0.10$ & $0.73 \pm 0.15$ & $0.64 \pm 0.15$ & $0.68 \pm 0.10$ \\
\hline ADX & $0.63 \pm 0.05$ & $0.67 \pm 0.03$ & $0.70 \pm 0.04$ & $0.68 \pm 0.02$ & $0.68 \pm 0.02$ \\
\hline \multicolumn{6}{|c|}{ Ionized calcium, $m M$} \\
\hline Intact & $1.30 \pm 0.02$ & $1.29 \pm 0.01$ & $1.28 \pm 0.02$ & $1.27 \pm 0.01$ & $1.27 \pm 0.01$ \\
\hline ADX & $1.30 \pm 0.03$ & $' 1.28 \pm 0.02$ & $1.29 \pm 0.01$ & $1.26 \pm 0.03$ & $1.29 \pm 0.02$ \\
\hline \multicolumn{6}{|c|}{ Arterial pH } \\
\hline Intact & $7.38 \pm 0.01$ & $7.44 \pm 0.02$ & $7.42 \pm 0.02$ & $7.44 \pm 0.01$ & $7.41 \pm 0.02$ \\
\hline ADX & $7.39 \pm 0.01$ & $7.38 \pm 0.01^{*}$ & $7.37 \pm 0.02^{*}$ & $7.37 \pm 0.01^{*}$ & $7.36 \pm 0.02^{* \ddagger}$ \\
\hline \multicolumn{6}{|c|}{ Bicarbonate, $m M$} \\
\hline Intact & $24.3 \pm 2.0$ & $23.7 \pm 1.2$ & $22.9 \pm 1.2$ & $23.0 \pm 0.6$ & $22.8 \pm 1.0$ \\
\hline ADX & $19.7 \pm 2.0^{*}$ & $19.2 \pm 1.9^{*}$ & $18.8 \pm 0.9^{*}$ & $16.5 \pm 2.0^{* \pm}$ & $15.6 \pm 2.2^{* \ddagger}$ \\
\hline \multicolumn{6}{|c|}{ iPTH, $p g / m l$} \\
\hline Intact & $26.8 \pm 2.5$ & $23.1 \pm 3.4$ & $25.7 \pm 3.2$ & $24.3 \pm 3.9$ & $26.7 \pm 2.3$ \\
\hline ADX & $29.3 \pm 7.3$ & $27.0 \pm 3.5$ & $28.3 \pm 6.0$ & $28.5 \pm 4.5$ & $33.5 \pm 2.0$ \\
\hline \multicolumn{6}{|c|}{ GFR, $\mathrm{ml} / \mathrm{min}$} \\
\hline Intact & \multicolumn{2}{|c|}{$1.16 \pm 0.13$} & $1.06 \pm 0.15$ & $1.06 \pm 0.15$ & $1.04 \pm 0.10$ \\
\hline ADX & \multicolumn{2}{|c|}{$0.89 \pm 0.12^{*}$} & $0.77 \pm 0.09^{*}$ & $0.61 \pm 0.06^{* \neq}$ & $0.57 \pm 0.12^{* \ddagger}$ \\
\hline \multicolumn{6}{|l|}{ Urine pH } \\
\hline Intact & \multicolumn{2}{|c|}{$6.43 \pm 0.02$} & $6.55 \pm 0.10$ & $6.62 \pm 0.08$ & $6.60 \pm 0.10$ \\
\hline ADX & \multicolumn{2}{|c|}{$5.49 \pm 0.08^{*}$} & $5.54 \pm 0.20^{*}$ & $5.60 \pm 0.30^{*}$ & $5.46 \pm 0.20^{*}$ \\
\hline \multicolumn{6}{|c|}{ (UV)Pi, $n m o l / m i n$} \\
\hline Intact & \multicolumn{2}{|c|}{$496 \pm 39$} & $314 \pm 69^{\ddagger}$ & $251 \pm 16^{\ddagger}$ & $187 \pm 12^{\ddagger}$ \\
\hline ADX & \multicolumn{2}{|c|}{$122 \pm 46^{*}$} & $123 \pm 50^{*}$ & $135 \pm 60$ & $159 \pm 74$ \\
\hline \multicolumn{6}{|l|}{ (FE) $\mathrm{Pi}$} \\
\hline Intact & \multicolumn{2}{|c|}{$0.20 \pm 0.02$} & $0.12 \pm 0.02^{\ddagger}$ & $0.11 \pm 0.01^{\ddagger}$ & $0.09 \pm 0.01^{\ddagger}$ \\
\hline ADX & \multicolumn{2}{|c|}{$0.06 \pm 0.03^{*}$} & $0.07 \pm 0.04$ & $0.09 \pm 0.04$ & $0.10 \pm 0.05$ \\
\hline \multicolumn{6}{|c|}{ NcAMP, $\mathrm{pmol} / \mathrm{min}$} \\
\hline Intact & \multicolumn{2}{|c|}{$48 \pm 4$} & $44 \pm 9$ & $50 \pm 12$ & $56 \pm 10$ \\
\hline ADX & \multicolumn{2}{|c|}{$51 \pm 16$} & $60 \pm 12$ & $45 \pm 15$ & $52 \pm 16$ \\
\hline
\end{tabular}

Values are means \pm SE in three intact and three ADX time-control rats. Pi, inorganic phosphorus; (UV), urinary excretion rate; (FE), urinary fractional excretion. ${ }^{*} P<0.05$ or less vs. same period in intact rats. ${ }^{\ddagger} P<0.05$ or less vs. control period in the same group.

Thus it is clear that acute metabolic acidosis was associated with biologically active increments in serum iPTH concentration independently of the currently known main acute determinants (calcium and magnesium) of endogenous PTH secretion.

\section{Renal response to acid loading}

The renal response to $\mathrm{HCl}$ loading was studied in various groups of rats, which allowed recognizing effects that were due to PTH.

Studies in adrenal-intact rats (groups $V$-VII). The arterial blood composition in these rats is summarized in Table II. As expected, plasma ionized calcium and magnesium concentration was lower and that of inorganic phosphorus higher in PTX rats than in animals that were intact or PTX infused with hPTH-(1-34) during both control and acidosis periods. It is important to note that during the control period the values of plasma ionized calcium concentration (Table II) and urinary phosphate fractional excretion (Fig. 4) produced by infusion in PTX rats of hPTH-(1-34) at 5-6 (group VIIa) and 7-9 pg/min per $\mathrm{g}$ body wt (group VIIb) were moderately lower and higher, respectively, than the values in intact rats; thus these two hPTH-(1-34) infusion rates produced low-normal and moderately high biological PTH circulating activities. Since hPTH-(1-34) and rat PTH-(1-84) do not have the same molar potency against the antiserum used in the present study (19), it was impossible to directly compare their circulating concentrations.

During $\mathrm{HCl}$ loading, PTX rats developed a metabolic acidosis that was significantly more severe than that of intact or hPTH-(1-34)-infused PTX rats; the arterial $\mathrm{pH}$ was lower after 2-3 $\mathrm{h}$ of $\mathrm{HCl}$ infusion in PTX than in other rats (Table II), and the decrease in the plasma bicarbonate concentration was higher in PTX rats $(-9.2 \pm 0.4 \mathrm{mmol} / \mathrm{liter})$ than in intact $(-8.3 \pm 0.5 \mathrm{mmol} / \mathrm{liter}, P<0.05)$ or PTX rats infused with a low dose $(-8.0 \pm 0.2 \mathrm{mmol} / \mathrm{liter}, P<0.05)$ or a high dose 

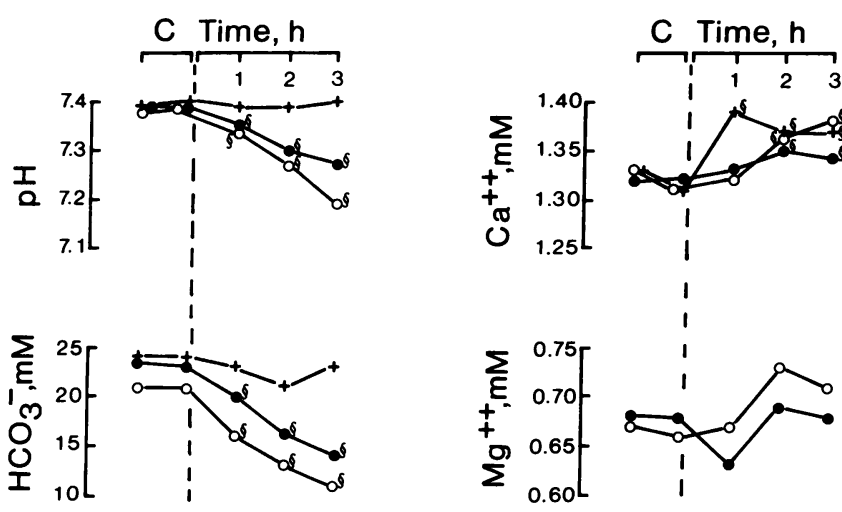

Figure 1. Arterial pH and concentrations of bicarbonate, ionized calcium, and magnesium during control period $(C), 3-\mathrm{h} \mathrm{HCl}$ infusion in intact $(n=6)(\bullet)$ or $\mathrm{ADX}(n=6)$ rats $(0)$, and 3-h $\mathrm{CaCl}_{2}$ infusion in intact rats $(n=3)(+)$. Magnesium was not measured in $\mathrm{CaCl}_{2}$-infused rats. Points are means \pm SE. ${ }^{\S}, P<0.05$ or less compared with control period.

$(-6.8 \pm 0.3 \mathrm{mmol} / \mathrm{liter}, P<0.001)$ of hPTH-(1-34). This was due, at least in part, to the defect in urinary acidification and net acid excretion observed in PTX rats, which will be shown below. Two rats of the latter group, one PTX and one TPTX, died during the third hour of $\mathrm{HCl}$ infusion of apparent sudden circulatory failure, probably due to severe acidosis.

During the control period, the GFR was moderately higher in PTX than in intact rats $(P<0.05$, Table III), probably because of hypocalcemia and absence of circulating PTH (1, 10); indeed, GFR values were lowered toward controls by hPTH-(1-34) infusion in PTX rats, apparently in a dose-dependent manner. Note that the GFR decreased during acid loading in all rats, and that during the second and third hours of acidosis there remained no difference in GFR between the various groups (Table III). Also, the filtered load of bicarbonate tended to be higher in PTX than in other rats during the control period, but significantly only when compared with PTX infused with a high dose of hPTH-(1-34) $(P<0.01$,

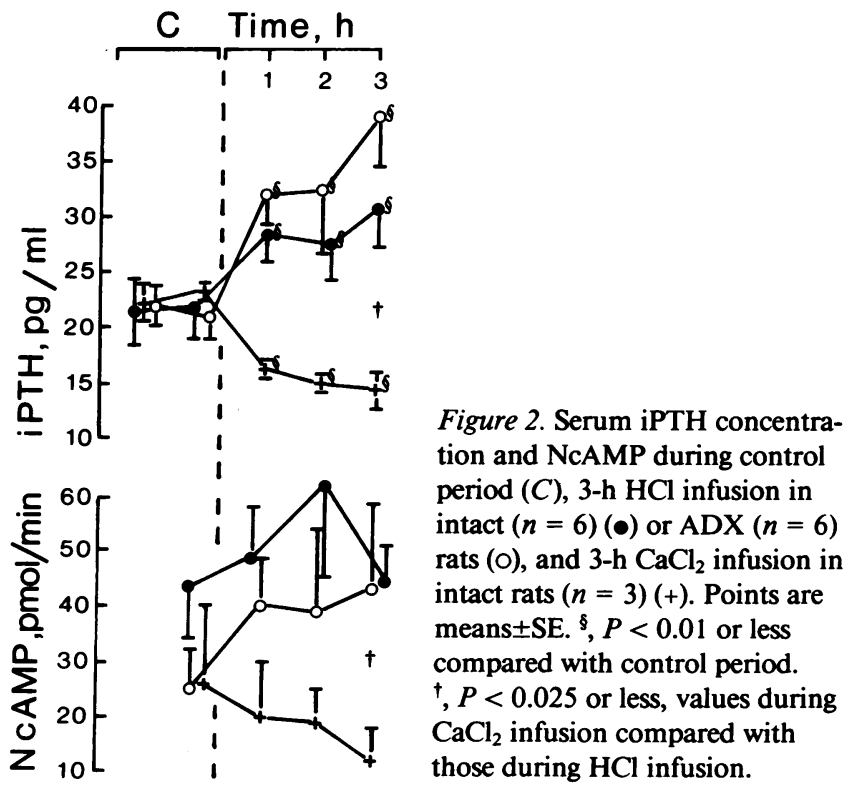

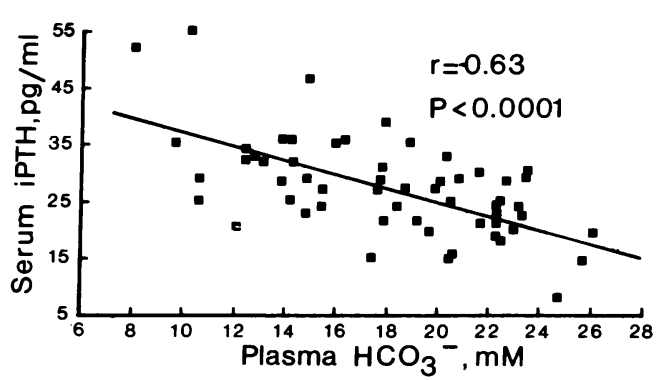

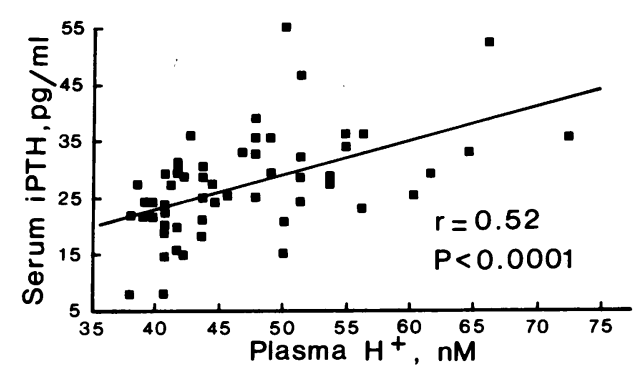

Figure 3. Relationships between serum iPTH concentration and arterial $\mathrm{HCO}_{3}^{-}$or $\mathrm{H}^{+}$concentration in six intact and six adrenalectomized rats during 3-h $\mathrm{HCl}$ infusion. Each point represents a single measurement in one animal.

Table III); any difference in the bicarbonate-filtered load between the various groups rapidly disappeared during acid loading.

As compared with intact rats, a marked defect in urinary acidification and urinary excretion rates of phosphate, titratable acid, ammonium, and net acid was observed in PTX animals during both control and acidosis periods (Table III, Figs. 4 and 5). The urinary bicarbonate excretion rate was not significantly different in PTX and intact rats during the control period and first hour of $\mathrm{HCl}$ infusion, and then fell to very low values in both groups during the last two hours of acidosis (Table III); nevertheless, the urine pH (Table III) remained significantly higher in PTX than in intact rats $(P<0.01)$ throughout the experiments despite more severe acidosis and less urinary buffer content (see below) in the former animals; this obviously was secondary to a defect in collecting duct proton secretion in PTX rats. There was almost no phosphate in the urine of PTX rats (Fig. 4), and the urinary excretion rate of titratable acid was low throughout the experiments in these animals (Fig. 5). As shown in Fig. 5, the urinary ammonium excretion rate was also lower in PTX than in intact rats during the control period $(P<0.02)$; during acidosis, this difference in ammonium excretion persisted but tended to diminish. As a result of these various defects, the urinary net acid excretion rate was lower during control period in PTX than in intact rats $(P<0.02$, Fig. 5), and significantly remained so during acidosis.

The infusion of hPTH-(1-34) in PTX rats corrected the defects just described in a dose-dependent manner during both control and acidosis periods. This was true for the urine $\mathrm{pH}$ and urinary bicarbonate excretion rate (Table III), as well as for the urinary excretion rates of phosphate (Fig. 4), titratable acid, ammonium, and net acid (Fig. 5). Moreover, from Figs. 4 and 5 , it is apparent that the values observed in intact rats for 
Table II. Arterial Blood Composition in Adrenal-intact HCl-loaded Rats (Groups V-VII)

\begin{tabular}{|c|c|c|c|c|c|}
\hline & \multicolumn{2}{|c|}{ Control period (h) } & \multicolumn{3}{|c|}{ HCl-loading (h) } \\
\hline & 0 & 1 & 1 & 2 & 3 \\
\hline \multicolumn{6}{|l|}{ Hematocrit, vol\% } \\
\hline Intact & $44.5 \pm 0.8$ & $44.4 \pm 0.9$ & $46.6 \pm 0.9$ & $45.9 \pm 1.2$ & $46.0 \pm 1.3$ \\
\hline PTX & $44.9 \pm 1.0$ & $45.4 \pm 1.0$ & $47.2 \pm 1.4$ & $47.0 \pm 1.6$ & $46.6 \pm 2.0$ \\
\hline PTX + low hPTH-(1-34) & $44.8 \pm 0.5$ & $45.7 \pm 0.6$ & $46.9 \pm 0.5$ & $47.1 \pm 1.1$ & $46.8 \pm 1.9$ \\
\hline PTX + high hPTH-(1-34) & $43.7 \pm 1.2$ & $44.1 \pm 0.8$ & $46.1 \pm 0.9$ & $45.8 \pm 1.0$ & $46.8 \pm 0.9$ \\
\hline \multicolumn{6}{|l|}{ Protein, $g / d l$} \\
\hline Intact & $4.4 \pm 0.2$ & $4.5 \pm 0.2$ & $4.5 \pm 0.2$ & $4.4 \pm 0.3$ & $4.3 \pm 0.2$ \\
\hline PTX & $4.5 \pm 0.1$ & $4.4 \pm 0.1$ & $4.4 \pm 0.1$ & $4.3 \pm 0.2$ & $4.1 \pm 0.2$ \\
\hline PTX + low hPTH-(1-34) & $4.1 \pm 0.3$ & $4.3 \pm 0.3$ & $4.2 \pm 0.2$ & $4.2 \pm 0.2$ & $4.1 \pm 0.3$ \\
\hline PTX + high hPTH-(1-34) & $4.3 \pm 0.2$ & $4.2 \pm 0.1$ & $4.3 \pm 0.1$ & $4.2 \pm 0.1$ & $4.3 \pm 0.1$ \\
\hline \multicolumn{6}{|l|}{ Sodium, $m M$} \\
\hline Intact & $147 \pm 1$ & $147 \pm 1$ & $144 \pm 1$ & $141 \pm 2 *$ & $138 \pm 2^{*}$ \\
\hline PTX & $146 \pm 1$ & $145 \pm 2$ & $142 \pm 2$ & $140 \pm 2 *$ & $138 \pm 3^{*}$ \\
\hline PTX + low hPTH-(1-34) & $147 \pm 3$ & $148 \pm 3$ & $145 \pm 2$ & $142 \pm 3^{*}$ & $138 \pm 2 *$ \\
\hline PTX + high hPTH-(1-34) & $146 \pm 1$ & $145 \pm 1$ & $143 \pm 1$ & $140 \pm 1^{*}$ & $138 \pm 1^{*}$ \\
\hline \multicolumn{6}{|l|}{ Potassium, $m M$} \\
\hline Intact & $3.9 \pm 0.1$ & $3.9 \pm 0.1$ & $4.1 \pm 0.1$ & $4.2 \pm 0.1$ & $4.1 \pm 0.1$ \\
\hline PTX & $3.5 \pm 0.1^{\ddagger}$ & $3.4 \pm 0.1^{\ddagger}$ & $3.5 \pm 0.1^{\ddagger}$ & $3.7 \pm 0.1^{\ddagger}$ & $3.8 \pm 0.3$ \\
\hline PTX + low hPTH-(1-34) & $3.8 \pm 0.1^{8}$ & $3.7 \pm 0.1^{\S}$ & $3.8 \pm 0.1^{8}$ & $4.0 \pm 0.1$ & $4.3 \pm 0.2$ \\
\hline PTX + high hPTH-(1-34) & $3.9 \pm 0.1^{8}$ & $3.8 \pm 0.1^{\S}$ & $3.8 \pm 0.1^{\S}$ & $4.0 \pm 0.1$ & $4.1 \pm 0.1$ \\
\hline \multicolumn{6}{|l|}{ Chloride, meq/liter } \\
\hline Intact & $112 \pm 1$ & $112 \pm 2$ & $113 \pm 2$ & $113 \pm 2$ & $115 \pm 2^{*}$ \\
\hline PTX & $110 \pm 1$ & $109 \pm 2$ & $110 \pm 2$ & $112 \pm 2^{*}$ & $112 \pm 2 *$ \\
\hline PTX + low hPTH-(1-34) & $115 \pm 3$ & $116 \pm 3$ & $116 \pm 2$ & $115 \pm 2$ & $117 \pm 3$ \\
\hline PTX + high hPTH-(1-34) & $112 \pm 1$ & $113 \pm 1$ & $114 \pm 1$ & $114 \pm 1$ & $114 \pm 1$ \\
\hline \multicolumn{6}{|l|}{$\mathrm{Pi}, m M$} \\
\hline Intact & $2.20 \pm 0.05$ & $2.11 \pm 0.06$ & $2.12 \pm 0.06$ & $1.95 \pm 0.16$ & $2.11 \pm 0.08$ \\
\hline PTX & $2.55 \pm 0.11^{\ddagger}$ & $2.59 \pm 0.10^{\ddagger}$ & $2.73 \pm 0.11^{\ddagger}$ & $2.82 \pm 0.12^{* \ddagger}$ & $3.10 \pm 0.05^{* \pm}$ \\
\hline PTX + low hPTH-(1-34) & $2.20 \pm 0.07^{\S}$ & $2.23 \pm 0.07^{\S}$ & $2.24 \pm 0.04^{\S}$ & $2.25 \pm 0.05^{\S}$ & $2.26 \pm 0.08^{8}$ \\
\hline PTX + high hPTH-(1-34) & $1.95 \pm 0.07^{\ddagger \S}$ & $1.86 \pm 0.06^{\ddagger \S ॥}$ & $1.87 \pm 0.06^{\ddagger \S ॥}$ & $1.81 \pm 0.08^{811}$ & $1.85 \pm 0.07^{+\$ \$ \mid}$ \\
\hline \multicolumn{6}{|l|}{ Magnesium, $m M$} \\
\hline Intact & $0.65 \pm 0.01$ & $0.63 \pm 0.01$ & $0.65 \pm 0.02$ & $0.66 \pm 0.03$ & $0.74 \pm 0.07$ \\
\hline PTX & $0.54 \pm 0.02^{\ddagger}$ & $0.52 \pm 0.03^{\ddagger}$ & $0.53 \pm 0.04^{\ddagger}$ & $0.58 \pm 0.03$ & $0.62 \pm 0.05^{*}$ \\
\hline PTX + low hPTH-(1-34) & $0.62 \pm 0.04^{\S}$ & $0.59 \pm 0.04^{8}$ & $0.58 \pm 0.02$ & $0.57 \pm 0.04$ & $0.63 \pm 0.04$ \\
\hline PTX + high hPTH-(1-34) & $0.63 \pm 0.01^{\S}$ & $0.61 \pm 0.02^{\S}$ & $0.60 \pm 0.03^{8}$ & $0.59 \pm 0.04$ & $0.63 \pm 0.06$ \\
\hline \multicolumn{6}{|l|}{ Total calcium, $m M$} \\
\hline Intact & $2.15 \pm 0.03$ & $2.15 \pm 0.04$ & $2.17 \pm 0.04$ & $2.17 \pm 0.05$ & $2.15 \pm 0.05$ \\
\hline PTX & $1.80 \pm 0.03^{\ddagger}$ & $1.75 \pm 0.07^{\ddagger}$ & $1.76 \pm 0.04^{\ddagger}$ & $1.77 \pm 0.05^{\ddagger}$ & $1.75 \pm 0.05^{\ddagger}$ \\
\hline PTX + low hPTH-(1-34) & $2.06 \pm 0.05^{\S}$ & $2.10 \pm 0.03^{8}$ & $2.10 \pm 0.02^{8}$ & $2.09 \pm 0.05^{8}$ & $2.06 \pm 0.06^{8}$ \\
\hline PTX + high hPTH-(1-34) & $2.18 \pm 0.05^{\S}$ & $2.24 \pm 0.05^{\S \|}$ & $2.28 \pm 0.03^{8 \| \prime}$ & $2.20 \pm 0.05^{8}$ & $2.21 \pm 0.05^{\S}$ \\
\hline \multicolumn{6}{|l|}{ Ionized calcium, $m M$} \\
\hline Intact & $1.29 \pm 0.01$ & $1.29 \pm 0.01$ & $1.32 \pm 0.01$ & $1.32 \pm 0.02$ & $1.33 \pm 0.02^{*}$ \\
\hline PTX & $1.08 \pm 0.02^{\ddagger}$ & $1.05 \pm 0.02^{\ddagger}$ & $1.05 \pm 0.02^{\ddagger}$ & $1.09 \pm 0.02^{* \neq}$ & $1.13 \pm 0.02^{* \neq}$ \\
\hline PTX + low hPTH-(1-34) & $1.25 \pm 0.03^{\S}$ & $1.17 \pm 0.02^{\S}$ & $1.31 \pm 0.02^{\S}$ & $1.32 \pm 0.01^{* \delta}$ & $1.32 \pm 0.01^{\star \xi}$ \\
\hline PTX + high hPTH-(1-34) & $1.34 \pm 0.02^{\ddagger \S ॥}$ & $1.34 \pm 0.01^{\ddagger \$ \|}$ & $1.35 \pm 0.01^{\S}$ & $1.36 \pm 0.01^{* \S}$ & $1.37 \pm 0.02^{\star \S}$ \\
\hline \multicolumn{6}{|l|}{ pH } \\
\hline Intact & $7.40 \pm 0.01$ & $7.40 \pm 0.01$ & $7.33 \pm 0.02^{*}$ & $7.29 \pm 0.02^{*}$ & $7.25 \pm 0.02^{*}$ \\
\hline PTX & $7.40 \pm 0.01$ & $7.39 \pm 0.01$ & $7.32 \pm 0.01^{*}$ & $7.25 \pm 0.01^{* \ddagger}$ & $7.20 \pm 0.01^{* \ddagger}$ \\
\hline PTX + low hPTH-(1-34) & $7.39 \pm 0.01$ & $7.37 \pm 0.01$ & $7.35 \pm 0.01^{*}$ & $7.30 \pm 0.02^{* \S}$ & $7.23 \pm 0.03^{*}$ \\
\hline PTX + high hPTH-(1-34) & $7.40 \pm 0.01$ & $7.40 \pm 0.01$ & $7.36 \pm 0.01^{* \S}$ & $7.30 \pm 0.01^{\star \delta}$ & $7.26 \pm 0.01^{\star \delta}$ \\
\hline \multicolumn{6}{|l|}{ Bicarbonate, $m M$} \\
\hline Intact & $23.5 \pm 0.8$ & $23.0 \pm 0.7$ & $19.3 \pm 0.7^{*}$ & $16.5 \pm 0.7^{*}$ & $14.8 \pm 0.6^{*}$ \\
\hline PTX & $23.6 \pm 0.4$ & $22.8 \pm 0.6$ & $18.7 \pm 0.1^{*}$ & $15.7 \pm 0.5^{*}$ & $13.4 \pm 0.6^{*}$ \\
\hline PTX + low hPTH-(1-34) & $22.1 \pm 0.9$ & $21.7 \pm 1.2$ & $18.9 \pm 0.6^{*}$ & $16.1 \pm 0.3^{*}$ & $13.7 \pm 1.3^{*}$ \\
\hline PTX + high hPTH-(1-34) & $21.3 \pm 0.5$ & $21.2 \pm 0.5$ & $18.9 \pm 0.2^{*}$ & $15.5 \pm 0.4^{*}$ & $14.4 \pm 0.5^{*}$ \\
\hline \multicolumn{6}{|l|}{$\mathrm{PCO}_{2}, \mathrm{mmHg}$} \\
\hline Intact & $38 \pm 1$ & $38 \pm 2$ & $37 \pm 2$ & $35 \pm 2$ & $35 \pm 1$ \\
\hline PTX & $39 \pm 1$ & $37 \pm 1$ & $37 \pm 1$ & $36 \pm 1$ & $36 \pm 1$ \\
\hline PTX + low hPTH-(1-34) & $37 \pm 1$ & $35 \pm 1$ & $35 \pm 1$ & $33 \pm 1$ & $33 \pm 1$ \\
\hline PTX + high hPTH-(1-34) & $35 \pm 1$ & $34 \pm 1$ & $34 \pm 1$ & $33 \pm 1$ & $33 \pm 1$ \\
\hline
\end{tabular}

Values are means \pm SE in six intact rats, six PTX rats, and eight PTX rats infused with hPTH-(1-34) at low (5-6 pg/min per $\mathrm{g}$ body wt, $n=3$ ) and high $(7-9 \mathrm{pg} / \mathrm{min}$ per $\mathrm{g}$ body wt, $n=5)$ doses. There remained only four PTX rats at the third hour of $\mathrm{HCl}$ loading. Pi, inorganic phosphorus. ${ }^{*} P<0.05$ or less vs. control period in the same group. ${ }^{\ddagger} P<0.05$ or less vs. intact rats at the same period. ${ }^{\S} P<0.05$ or less vs. PTX rats at the same period. " $P<0.05$ or less vs. PTX rats infused with low-dose hPTH-(1-34) at the same period. 

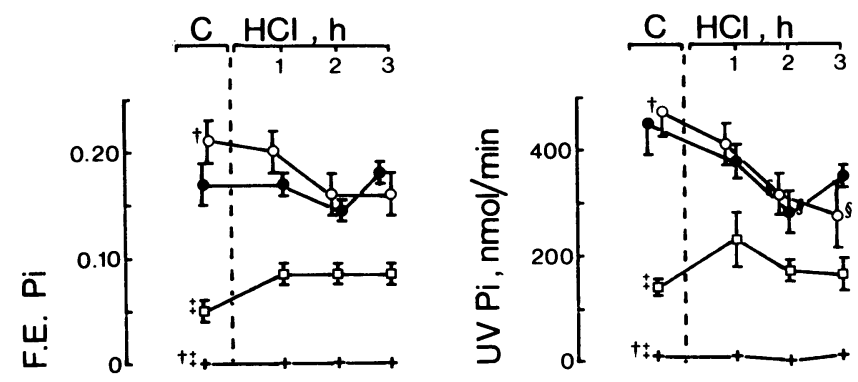

Figure 4. Urinary fractional (F.E.) and absolute (UV) excretion of inorganic phosphorus $(P i)$ during control period $(C)$ and $3-\mathrm{h} \mathrm{HCl}$ infusion in intact rats $(n=6)(\bullet)$, PTX rats $(n=6)(+)$, and PTX rats infused with low (5-6 pg/min per $\mathrm{g}$ body wt, $n=3$ ) ( $\square$ ) and high (o) $(7-9 \mathrm{pg} / \mathrm{min}$ per $\mathrm{g}$ body wt, $n=5)$ doses of hPTH-(1-34). Note that only four PTX rats remained during the third hour of $\mathrm{HCl}$ infusion. Points are means \pm SE. ${ }^{\S}, P<0.05$ or less compared with control period; ${ }^{\ddagger}, P<0.05$ or less compared with intact rats. ${ }^{\dagger}, P<0.05$ or less compared with PTX rats infused with low hPTH-(1-34).

urinary phosphate, titratable acid, ammonium, and net acid excretion rates were intermediate to those obtained with lowdose and high-dose hPTH-(1-34) infusion in PTX rats, which clearly confirms the physiological dose-dependence with respect to PTH of the absolute values of the various components of urinary net acid excretion. However, for a given level of absolute excretion, the evolution of the latter parameters of urinary acidification in response to $\mathrm{HCl}$ loading in the various experimental groups must be considered. Despite the decrease in the filtered phosphate load during $\mathrm{HCl}$ loading, urinary phosphate fractional and absolute excretion was maintained or decreased only moderately in intact and hPTH-(1-34) infused PTX rats during $\mathrm{HCl}$ loading (Fig. 4), whereas it greatly decreased in time-control, nonacidotic rats (Table I); due to the simultaneous decrease in the urine $\mathrm{pH}$ during acidosis, the urinary titratable acid excretion rate increased progressively and significantly at the third hour of acidosis in intact rats $(P$ $<0.02$ vs. control period) and was maintained in hPTH-( $1-$ 34)-infused PTX rats (Fig. 5); in PTX rats, the urinary excretion rates of phosphate and titratable acid remained very low during acidosis. The urinary excretion rates of ammonium and net acid similarly increased in intact, hPTH-(1-34)-infused PTX, as well as in PTX rats, although different absolute levels due to different circulating PTH biological activities were evident (Fig. 5). As already mentioned, the presence of an intact endogenous corticosteroid secretion that may be stimulated during acidosis in the rat $(14,17)$ could have clouded possible differences in the renal response to acidosis due to PTH, particularly as various degrees of acidosis were attained in these four groups of rats as described above.

Studies in $A D X$ rats (groups VIII-X). As already pointed out in Methods, this experimental series that included ADX rats was designed to assess the role of PTH during acute metabolic acidosis in the absence of varying corticosteroid circulating activities.

The arterial blood composition in these rats is summarized in Table IV. It must be pointed out that only two of the six ADX-TPTX rats that composed group $\mathrm{X}$ have been studied during an entire 3-h period of acidosis because four rats died during the third hour of $\mathrm{HCl}$ infusion of apparent sudden circulatory failure, probably due to severe acidosis and/or hyperkalemia. A seventh ADX-TPTX rat that was not included in the group even died during the second hour of $\mathrm{HCl}$ infusion of profound metabolic acidosis. As will be shown below, this was due at least in part to the absence of a significant increase in the urinary net acid excretion rate during $\mathrm{HCl}$ loading in ADX-TPTX rats. Also, one PTX and one TPTX rat of group II died during the third hour of $\mathrm{HCl}$ infusion, as already mentioned, which suggests that extrarenal factors may also have contributed to the poor endurance to acid loading of PTX animals. A high rate of mortality had previously been observed by others during acute acid loading in nephrectomized TPTX animals $(23,24)$.

During both control and acidosis periods, the GFR was significantly lower in ADX and ADX-TPTX than in intact rats (Table $\mathrm{V}$ ), presumably because of low circulating levels of glucocorticosteroids in the former animals. However, high urinary sodium chloride excretion rates were observed in all rats, which was probably due to the fluid volume expansion and attendant suppression of endogenous aldosterone secretion in adrenal-intact rats secondary to our experimental protol, as mentioned in Methods, which minimized possible differences in body fluid volumes between ADX and adrenal-intact animals. In keeping with the above, there was no significant difference between the various groups of this study in the hematocrit and plasma protein concentration (Tables II and IV). At any rate, $\mathrm{ADX}$ and $\mathrm{ADX}$-TPTX rats can be readily compared and did not differ during the control period with respect to GFR and urinary excretion rates of water, sodium, chloride, and potassium.

As shown in Table $\mathrm{V}$, the urinary bicarbonate excretion rate significantly decreased in all groups during $\mathrm{HCl}$ infusion; the urinary $\mathrm{pH}$ also tended to decrease in all groups, but only significantly at the third hour of $\mathrm{HCl}$ loading in intact rats. Also, note that the urinary pH tended to be higher in ADXTPTX than in ADX rats throughout the study despite a more severe metabolic acidosis in the former animals, probably due to the defect in collecting duct proton secretion in PTX animals described above. The other components of the renal response to $\mathrm{HCl}$ loading markedly differed between intact and ADX rats on the one hand, and ADX-TPTX rats on the other hand, whereas acute metabolic acidosis was associated with a decrease in GFR of similar magnitude (20-25\%) in all animals (Table V). As shown in Fig. 6, the urinary fractional excretion rate of phosphate increased during $\mathrm{HCl}$ loading in intact and ADX rats, particularly in ADX rats in which it was low during the control period. As a result, the absolute excretion rates of phosphate (Fig. 6) and titratable acid (Fig. 7) were maintained in intact and increased in ADX rats despite the fall in GFR and phosphate-filtered load during $\mathrm{HCl}$ loading. Note that, conversely, in time-control animals the absolute and fractional urinary excretion of phosphate progressively decreased with time in intact rats or did not vary significantly in ADX rats in the absence of $\mathrm{HCl}$ infusion (Table I). Also, as shown in Fig. 7, significant increases in the urinary excretion rates of ammonium and net acid rapidly occurred in intact and ADX rats. Particularly, it is worth pointing out that the urinary ammonium excretion rate significantly increased in $\mathrm{ADX}$ rats very rapidly during the first hour of $\mathrm{HCl}$ infusion $(P<0.01$; Fig. 7). Net acid excretion increased $43 \%$ in intact and $56 \%$ in ADX rats after $3 \mathrm{~h}$ of acid loading ( $P<0.001$ for each). On the other 
Table III. GFR and Urinary Excretion Rates in Adrenal-intact HCl-loaded Rats (Groups V-VII)

\begin{tabular}{|c|c|c|c|c|}
\hline & \multirow[b]{2}{*}{ Control period } & \multicolumn{3}{|c|}{$\mathrm{HCl}$ loading (min) } \\
\hline & & $0-60$ & $60-120$ & $120-180$ \\
\hline \multicolumn{5}{|l|}{ GFR, $\mathrm{ml} / \mathrm{min}$} \\
\hline Intact & $1.24 \pm 0.06$ & $1.06 \pm 0.07$ & $0.94 \pm 0.10^{*}$ & $0.94 \pm 0.09^{*}$ \\
\hline PTX & $1.39 \pm 0.08^{\ddagger}$ & $1.26 \pm 0.06^{\ddagger}$ & $1.06 \pm 0.13$ & $1.04 \pm 0.05^{*}$ \\
\hline PTX + low hPTH-(1-34) & $1.31 \pm 0.02$ & $1.16 \pm 0.02$ & $1.04 \pm 0.07$ & $0.92 \pm 0.06^{*}$ \\
\hline PTX + high hPTH-(1-34) & $1.22 \pm 0.05^{\S}$ & $1.13 \pm 0.04$ & $1.10 \pm 0.05$ & $1.00 \pm 0.05^{*}$ \\
\hline \multicolumn{5}{|l|}{ Urine flow rate, $\mu \mathrm{l} / \mathrm{min}$} \\
\hline Intact & $67 \pm 9$ & $57 \pm 12$ & $46 \pm 16$ & $39 \pm 10$ \\
\hline PTX & $60 \pm 8$ & $54 \pm 9$ & $40 \pm 13$ & $26 \pm 9$ \\
\hline PTX + low hPTH-(1-34) & $62 \pm 6$ & $49 \pm 9$ & $33 \pm 10$ & $22 \pm 9$ \\
\hline PTX + high hPTH-(1-34) & $62 \pm 5$ & $49 \pm 3$ & $31 \pm 6$ & $45 \pm 5^{\prime \prime}$ \\
\hline \multicolumn{5}{|l|}{ Urine osmolality, mosmol/ $/ \mathrm{kg} \mathrm{H}_{2} \mathrm{O}$} \\
\hline Intact & $389 \pm 43$ & $457 \pm 99$ & $559 \pm 124$ & $517 \pm 60$ \\
\hline PTX & $407 \pm 52$ & $447 \pm 74$ & $296 \pm 30$ & $471 \pm 117$ \\
\hline PTX + low hPTH-(1-34) & $304 \pm 49$ & $336 \pm 83$ & $487 \pm 155$ & $752 \pm 148$ \\
\hline PTX + high hPTH-(1-34) & $341 \pm 32$ & $358 \pm 54$ & $503 \pm 81$ & $400 \pm 55$ \\
\hline \multicolumn{5}{|l|}{ Filtered bicarbonate, $\mathrm{nmol} / \mathrm{min}$} \\
\hline Intact & $31,637 \pm 1,611$ & $24,296 \pm 1,889^{*}$ & $18,634 \pm 1,864^{*}$ & $16,045 \pm 1,516^{*}$ \\
\hline PTX & $35,597 \pm 2,041$ & $28,634 \pm 1,105^{* \neq}$ & $20,109 \pm 2,584^{*}$ & $16,712 \pm 1,134^{*}$ \\
\hline PTX + low hPTH-(1-34) & $31,369 \pm 1,144$ & $25,885 \pm 1,685^{*}$ & $19,839 \pm 1,348^{*}$ & $15,105 \pm 1,755^{*}$ \\
\hline PTX + high hPTH-(1-34) & $28,353 \pm 1,464^{\S}$ & $24,953 \pm 994^{* \S}$ & $20,768 \pm 1,084^{*}$ & $16,052 \pm 1,464^{*}$ \\
\hline \multicolumn{5}{|l|}{ Urine $\mathrm{pH}$} \\
\hline Intact & $6.37 \pm 0.14$ & $6.18 \pm 0.15$ & $5.78 \pm 0.06^{*}$ & $5.54 \pm 0.07^{*}$ \\
\hline PTX & $6.81 \pm 0.05^{\ddagger}$ & $6.66 \pm 0.08^{\ddagger}$ & $6.10 \pm 0.15^{* \pm}$ & $5.87 \pm 0.11^{* \neq}$ \\
\hline PTX + low hPTH-(1-34) & $6.35 \pm 0.27^{\S}$ & $6.03 \pm 0.30^{\S}$ & $5.75 \pm 0.27^{\star \S}$ & $5.62 \pm 0.06^{* \S}$ \\
\hline PTX + high hPTH-(1-34) & $6.16 \pm 0.07^{8}$ & $6.00 \pm 0.07^{8}$ & $5.81 \pm 0.05^{\star \delta}$ & $5.69 \pm 0.05^{*}$ \\
\hline \multicolumn{5}{|l|}{$(\mathrm{UV}) \mathrm{HCO}_{3}, \mathrm{nmol} / \mathrm{min}$} \\
\hline Intact & $200 \pm 61$ & $130 \pm 50$ & $18 \pm 8^{*}$ & $7 \pm 3^{*}$ \\
\hline PTX & $235 \pm 17$ & $179 \pm 43$ & $34 \pm 15^{*}$ & $10 \pm 4^{*}$ \\
\hline PTX + low hPTH-(1-34) & $109 \pm 69^{\S}$ & $46 \pm 33^{\S}$ & $13 \pm 10^{*}$ & $4 \pm 1^{*}$ \\
\hline PTX + high hPTH-(1-34) & $59 \pm 11^{8}$ & $31 \pm 6^{\ddagger \S}$ & $9 \pm 2 *$ & $10 \pm 3^{*}$ \\
\hline \multicolumn{5}{|l|}{ (UV)Na, $\mathrm{nmol} / \mathrm{min}$} \\
\hline Intact & $8,818 \pm 1,062$ & $6,260 \pm 903$ & $4,777 \pm 1,315^{*}$ & $4,560 \pm 806^{*}$ \\
\hline PTX & $8,069 \pm 671$ & $6,642 \pm 1,242$ & $3,684 \pm 1,153^{*}$ & $2,947 \pm 1,270^{*}$ \\
\hline PTX + low hPTH-(1-34) & $6,462 \pm 685$ & $4,668 \pm 255$ & $3,463 \pm 872^{*}$ & $3,284 \pm 1,337^{*}$ \\
\hline PTX + high hPTH-(1-34) & $6,945 \pm 428$ & $6,039 \pm 903$ & $3,314 \pm 480^{*}$ & $4,131 \pm 806^{*}$ \\
\hline \multicolumn{5}{|l|}{ (UV)Cl, $\mathrm{nmol} / \mathrm{min}$} \\
\hline Intact & $9,725 \pm 996$ & $6,815 \pm 1,144$ & $6,320 \pm 1,336$ & $6,557 \pm 927$ \\
\hline PTX & $9,749 \pm 794$ & $8,220 \pm 1,331$ & $5,531 \pm 1,372^{*}$ & $4,950 \pm 1,485^{*}$ \\
\hline PTX + low hPTH-(1-34) & $7,704 \pm 764$ & $5,822 \pm 460$ & $5,227 \pm 1,091^{*}$ & $5,241 \pm 1,584^{*}$ \\
\hline PTX + high hPTH-(1-34) & $8,251 \pm 421$ & $7,597 \pm 551$ & $5,227 \pm 497^{*}$ & $6,593 \pm 927$ \\
\hline \multicolumn{5}{|l|}{ (UV)K, $\mathrm{nmol} / \mathrm{min}$} \\
\hline Intact & $1,022 \pm 71$ & $831 \pm 58$ & $947 \pm 127$ & $1,179 \pm 130$ \\
\hline PTX & $878 \pm 95$ & $731 \pm 90$ & $738 \pm 169$ & $796 \pm 254$ \\
\hline PTX + low hPTH-(1-34) & $669 \pm 82$ & $609 \pm 98$ & $685 \pm 89$ & $1,082 \pm 83$ \\
\hline PTX + high hPTH-(1-34) & $839 \pm 98$ & $839 \pm 82$ & $792 \pm 29$ & $1,179 \pm 130$ \\
\hline \multicolumn{5}{|l|}{ (UV)Ca, $n \mathrm{~mol} / \mathrm{min}$} \\
\hline Intact & $82 \pm 12$ & $79 \pm 14$ & $61 \pm 19$ & $61 \pm 19$ \\
\hline PTX & $113 \pm 19$ & $88 \pm 12$ & $64 \pm 20$ & $71 \pm 17$ \\
\hline PTX + low hPTH-(1-34) & $72 \pm 15$ & $74 \pm 21$ & $49 \pm 9$ & $61 \pm 10$ \\
\hline PTX + high hPTH-(1-34) & $63 \pm 15$ & $67 \pm 9$ & $37 \pm 7$ & $61 \pm 19$ \\
\hline \multicolumn{5}{|l|}{ (UV)Mg, nmol/min } \\
\hline Intact & $169 \pm 10$ & $137 \pm 12$ & $124 \pm 18$ & $128 \pm 10$ \\
\hline PTX & $162 \pm 10$ & $142 \pm 11$ & $121 \pm 18$ & $138 \pm 26$ \\
\hline PTX + low hPTH-(1-34) & $152 \pm 14$ & $128 \pm 15$ & $110 \pm 7$ & $88 \pm 5$ \\
\hline PTX + high hPTH-(1-34) & $125 \pm 16$ & $110 \pm 24$ & $86 \pm 19$ & $107 \pm 20$ \\
\hline
\end{tabular}

Values are means \pm SE. See Table II for definitions of groups and comparisons. (UV), urinary excretion rate. 


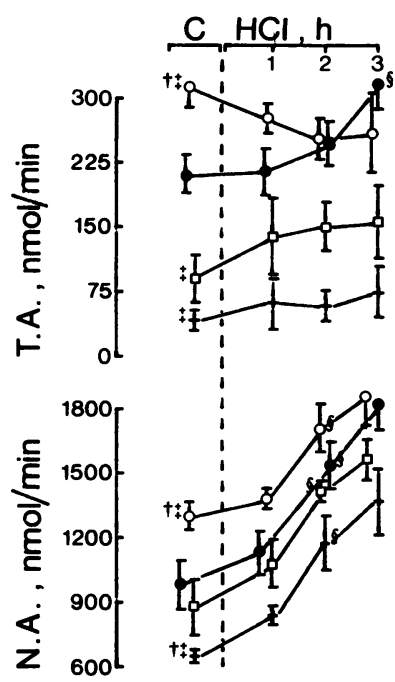

(O) dose of hPTH-(1-34). Note that there remained only four PTX rats during the third hour of $\mathrm{HCl}$ infusion. Points are means $\pm \mathrm{SE} .{ }^{\S}, P$ $<0.05$ or less compared with control period; ${ }^{\ddagger}, P<0.05$ or less compared with intact rats. ${ }^{\dagger}, P<\mathbf{0 . 0 5}$ or less compared with PTX rats infused with low hPTH-(1-34).

hand, in ADX-TPTX rats urinary excretion of phosphate, titratable acid, and ammonium did not rise during $\mathrm{HCl}$ infusion. Thus net acid excretion did not increase significantly in two ADX-TPTX rats after $3 \mathrm{~h}$ or in six ADX-TPTX rats after 1 and $2 \mathrm{~h}$ of $\mathrm{HCl}$ loading, i.e., at times when it was significantly enhanced in intact or ADX rats. Thus the renal response to acute metabolic acidosis was greatly blunted in ADX-TPTX rats as compared with intact, PTX, and ADX animals.

\section{Discussion}

The findings in the present study demonstrate in rats for the first time that an acute $\mathrm{HCl}$-induced metabolic acidosis results in a rapid and progressive increase in the circulating iPTH activity, and that PTH contributes to the renal response against acute metabolic acidosis by enhancing urinary phosphate, titratable acid, ammonium, and thus net acid excretion. The acidosis-induced increase in the circulating iPTH activity occurred in both intact and ADX rats, and was observed de-

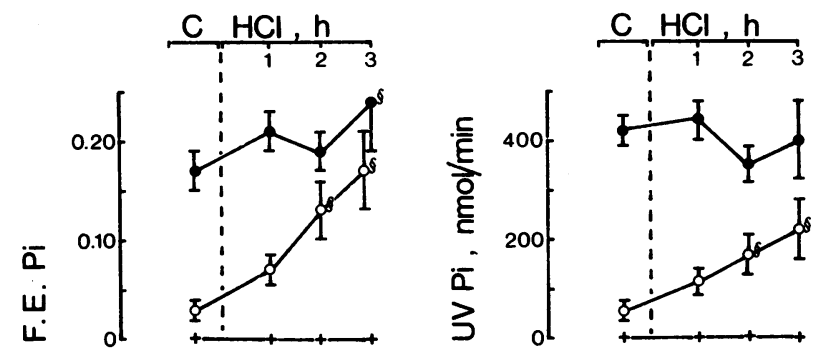

Figure 6. Urinary fractional (F.E.) and absolute $(U V)$ excretion of inorganic phosphorus $(P i)$ during control period $(C)$ and $3-\mathrm{h} \mathrm{HCl}$ infusion in intact $(n=6)(\bullet), \mathrm{ADX}(n=6)(0)$, and ADX-TPTX ( $n$ $=6$ ) rats $(+)$. Note that there remained only two ADX-TPTX rats during the third hour of $\mathrm{HCl}$ infusion. Points are means $\pm \mathrm{SE}$. $\$, P$ $<0.02$ or less compared with control period. spite an increase in the plasma ionized calcium concentration and no change in the plasma magnesium concentration. Thus a possible stimulation of endogenous PTH secretion was due to factors other than plasma calcium, magnesium, and adrenal hormones. Also, the rapid time-course of PTH stimulation ruled out a change in 1,25-dihydroxyvitamin $\mathrm{D}$ as a possible mediator of the acidosis effect. Strong linear relationships were observed between circulating iPTH levels and plasma bicarbonate or hydrogen ion concentration.

Normally the kidneys respond to acute and chronic acid loading by reducing the urinary.pH and bicarbonate excretion rate, at least temporarily, and by enhancing the urinary excretion rates of phosphate and titratable acid and particularly of ammonium so that net acid excretion is augmented until the entire acid load is excreted out of the body. The factors that are responsible for the renal adaptation to metabolic acidosis are at present incompletely settled. In recent reviews (25-27) it is generally accepted that acidosis itself exerts major effects on proximal and distal parts of the nephron to increase proton secretion and bicarbonate absorption, ammonia production and excretion, and phosphate and titratable acid excretion. However, the control of this important kidney function by hormonal factors must be considered. A role for corticosteroid hormones in the renal regulation of acid-base balance has been proposed in previous studies, in which acute and chronic acid loading were shown to increase the plasma aldosterone concentration in humans, rats, and dogs (15-18) and the plasma glucocorticosteroid concentration in dogs and rats $(14,16)$ but not in humans $(15,18)$. Although aldosterone is known to stimulate proton secretion in collecting ducts (reviewed in reference 28 ), to what extent the acidosis-induced increment in the circulating aldosterone level contributes to the renal response against acidosis remains to be established. The presence of circulating glucocorticosteroids has been shown to be necessary for a normal adaptive increase in renal ammonia and phosphate excretion in response to acute and chronic metabolic acidosis in the rat $(17,29-32)$. Results in the present study also support the hypothesis of a role for adrenal hormones in the renal response to acute metabolic acidosis inasmuch as absolute values of urinary excretion rates of phosphate, ammonium, and thus net acid were lower in ADX than in intact rats during both control and acidosis periods. Nevertheless, net acid excretion did increase $56 \%$ after $3-\mathrm{h} \mathrm{HCl}$ loading in ADX animals, as compared with an increase of $43 \%$ in intact rats in the same experimental series (Fig. 7). This observation is in agreement with results obtained in previous studies $(17,29)$ in which urinary net acid excretion increased in chronically ADX rats, although at rates that were lower than those in intact rats, during the first few hours after ammonium chloride loading. A role for PTH in this adaptive renal response to acute metabolic acidosis in intact and ADX animals is demonstrated in the present work.

In this study acute $\mathrm{HCl}$-induced metabolic acidosis in intact and ADX rats resulted in significant increases in IPTH activities that occurred despite significant increases in the plasma ionized calcium concentration. Serum iPTH was measured using an antiserum directed against the $\mathrm{NH}_{2}$-terminal bioactive region of PTH. We found that the basal serum iPTH concentration was $20-25 \mathrm{pg} / \mathrm{ml}$ in rats under our experimental conditions, which is in good agreement with values of 10-15 $\mathrm{pg} / \mathrm{ml}$ obtained by others in the rat with the same radioimmu- 
Table IV. Arterial Blood Composition in ADX HCl-loaded Rats (Groups VIII-X)

\begin{tabular}{|c|c|c|c|c|c|}
\hline & \multicolumn{2}{|c|}{ Control period (h) } & \multicolumn{3}{|c|}{$\mathrm{HCl}$ loading (h) } \\
\hline & 0 & 1 & 1 & 2 & 3 \\
\hline \multicolumn{6}{|l|}{ Hematocrit, vol\% } \\
\hline Intact & $43.0 \pm 0.7$ & $43.3 \pm 0.7$ & $45.1 \pm 0.9$ & $45.7 \pm 0.8$ & $45.5 \pm 0.8$ \\
\hline ADX & $42.9 \pm 1.4$ & $42.0 \pm 1.2$ & $42.5 \pm 0.8$ & $42.4 \pm 0.8$ & $42.6 \pm 0.8$ \\
\hline ADX-TPTX & $43.1 \pm 0.8$ & $43.7 \pm 0.6$ & $44.2 \pm 0.6$ & $44.1 \pm 0.4$ & $43.8 \pm 1.0$ \\
\hline \multicolumn{6}{|l|}{ Protein, $g / d l$} \\
\hline Intact & $4.0 \pm 0.2$ & $3.9 \pm 0.2$ & $3.8 \pm 0.2$ & $3.8 \pm 0.2$ & $3.6 \pm 0.2$ \\
\hline $\mathrm{ADX}$ & $3.6 \pm 0.1$ & $3.3 \pm 0.2$ & $3.3 \pm 0.2$ & $3.2 \pm 0.2$ & $3.2 \pm 0.1$ \\
\hline ADX-TPTX & $3.6 \pm 0.2$ & $3.2 \pm 0.2$ & $3.1 \pm 0.2$ & $3.0 \pm 0.2$ & $3.0 \pm 0.2$ \\
\hline \multicolumn{6}{|l|}{ Sodium, $m M$} \\
\hline Intact & $143 \pm 2$ & $145 \pm 2$ & $144 \pm 2$ & $142 \pm 2$ & $140 \pm 2^{*}$ \\
\hline ADX & $145 \pm 2$ & $145 \pm 2$ & $143 \pm 2$ & $139 \pm 1^{*}$ & $137 \pm 3^{*}$ \\
\hline ADX-TPTX & $141 \pm 3$ & $141 \pm 4$ & $143 \pm 3$ & $137 \pm 3$ & $134 \pm 4^{*}$ \\
\hline \multicolumn{6}{|l|}{ Potassium, $m M$} \\
\hline Intact & $3.7 \pm 0.3$ & $3.7 \pm 0.2$ & $3.6 \pm 0.2$ & $3.8 \pm 0.2$ & $4.0 \pm 0.2$ \\
\hline ADX & $4.0 \pm 0.2$ & $3.9 \pm 0.1$ & $4.1 \pm 0.3$ & $4.4 \pm 0.3^{*}$ & $4.4 \pm 0.6^{*}$ \\
\hline ADX-TPTX & $3.8 \pm 0.1$ & $3.9 \pm 0.1$ & $4.1 \pm 0.2$ & $4.8 \pm 0.3^{* \pm}$ & $5.0 \pm 0.5^{* \neq \S}$ \\
\hline \multicolumn{6}{|c|}{ Chloride, meq/liter } \\
\hline Intact & $115 \pm 1$ & $114 \pm 1$ & $117 \pm 2$ & $118 \pm 3^{*}$ & $117 \pm 1^{*}$ \\
\hline ADX & $114 \pm 1$ & $114 \pm 2$ & $115 \pm 1$ & $117 \pm 1^{*}$ & $119 \pm 2 *$ \\
\hline ADX-TPTX & $112 \pm 1$ & $113 \pm 1$ & $115 \pm 2$ & $118 \pm 2 *$ & $117 \pm 3^{*}$ \\
\hline \multicolumn{6}{|l|}{$\mathrm{Pi}, m M$} \\
\hline Intact & $2.6 \pm 0.2$ & $2.5 \pm 0.1$ & $2.4 \pm 0.2$ & $2.3 \pm 0.1$ & $2.1 \pm 0.2$ \\
\hline ADX & $2.9 \pm 0.3$ & $2.9 \pm 0.2$ & $2.9 \pm 0.2$ & $2.8 \pm 0.2$ & $2.9 \pm 0.6^{\ddagger}$ \\
\hline ADX-TPTX & $3.2 \pm 0.1^{\ddagger}$ & $3.4 \pm 0.1^{\ddagger}$ & $3.5 \pm 0.1^{\ddagger}$ & $3.7 \pm 0.3^{\ddagger \S}$ & $3.7 \pm 0.6^{\ddagger \S}$ \\
\hline \multicolumn{6}{|c|}{ Magnesium, $m M$} \\
\hline Intact & $0.67 \pm 0.02$ & $0.66 \pm 0.03$ & $0.63 \pm 0.02$ & $0.63 \pm 0.02$ & $0.63 \pm 0.03$ \\
\hline ADX & $0.68 \pm 0.03$ & $0.67 \pm 0.03$ & $0.70 \pm 0.04$ & $0.67 \pm 0.05$ & $0.68 \pm 0.05$ \\
\hline ADX-TPTX & $0.66 \pm 0.04$ & $0.64 \pm 0.03$ & $0.65 \pm 0.02$ & $0.65 \pm 0.01$ & $0.64 \pm 0.05$ \\
\hline \multicolumn{6}{|c|}{ Total calcium, $m M$} \\
\hline Intact & $2.06 \pm 0.05$ & $2.08 \pm 0.05$ & $2.04 \pm 0.06$ & $2.02 \pm 0.05$ & $2.02 \pm 0.04$ \\
\hline ADX & $2.13 \pm 0.06$ & $1.98 \pm 0.04$ & $1.98 \pm 0.03$ & $1.97 \pm 0.04$ & $1.99 \pm 0.02$ \\
\hline ADX-TPTX & $1.87 \pm 0.07$ & $1.92 \pm 0.06$ & $1.95 \pm 0.05$ & $1.97 \pm 0.06$ & $1.96 \pm 0.10$ \\
\hline \multicolumn{6}{|c|}{ Ionized calcium, $m M$} \\
\hline Intact & $1.30 \pm 0.01$ & $1.28 \pm 0.01$ & $1.30 \pm 0.0 .1$ & $1.32 \pm 0.02$ & $1.33 \pm 0.02^{*}$ \\
\hline ADX & $1.30 \pm 0.02$ & $1.28 \pm 0.01$ & $1.30 \pm 0.01$ & $1.34 \pm 0.02^{*}$ & $1.33 \pm 0.03^{*}$ \\
\hline ADX-TPTX & $1.27 \pm 0.03$ & $1.25 \pm 0.03$ & $1.36 \pm 0.05^{*}$ & $1.39 \pm 0.07^{*}$ & $1.35 \pm 0.08^{*}$ \\
\hline \multicolumn{6}{|l|}{$\mathrm{pH}$} \\
\hline Intact & $7.37 \pm 0.01$ & $7.37 \pm 0.01$ & $7.31 \pm 0.01^{*}$ & $7.25 \pm 0.03^{*}$ & $7.19 \pm 0.02^{*}$ \\
\hline ADX & $7.41 \pm 0.01$ & $7.40 \pm 0.02$ & $7.30 \pm 0.03^{*}$ & $7.24 \pm 0.03^{*}$ & $7.18 \pm 0.02^{*}$ \\
\hline ADX-TPTX & $7.38 \pm 0.02$ & $7.38 \pm 0.02$ & $7.28 \pm 0.03^{*}$ & $7.18 \pm 0.05^{* \pm}$ & $7.13 \pm 0.06^{* \ddagger}$ \\
\hline \multicolumn{6}{|c|}{ Bicarbonate, $m M$} \\
\hline Intact & $21.6 \pm 0.3$ & $22.2 \pm 0.5$ & $18.5 \pm 0.8^{*}$ & $16.4 \pm 0.9^{*}$ & $14.0 \pm 1.2^{*}$ \\
\hline ADX & $20.6 \pm 0.3$ & $20.4 \pm 0.4$ & $16.6 \pm 0.8^{*}$ & $13.9 \pm 1.0^{*}$ & $12.6 \pm 1.2^{*}$ \\
\hline ADX-TPTX & $20.8 \pm 0.5$ & $20.5 \pm 0.6$ & $16.0 \pm 0.9^{* \pm}$ & $13.1 \pm 1.2^{* \pm}$ & $11.0 \pm 1.9^{* \neq}$ \\
\hline \multicolumn{6}{|l|}{$\mathrm{PCO}_{2}, \mathrm{mmHg}$} \\
\hline Intact & $39 \pm 1$ & $39 \pm 1$ & $38 \pm 1$ & $37 \pm 1$ & $37 \pm 2$ \\
\hline ADX & $33 \pm 1$ & $34 \pm 2$ & $35 \pm 2$ & $35 \pm 2$ & $34 \pm 1$ \\
\hline ADX-TPTX & $36 \pm 1$ & $35 \pm 1$ & $36 \pm 2$ & $36 \pm 2$ & $33 \pm 2$ \\
\hline
\end{tabular}

Values are means \pm SE in six intact rats, six ADX rats, and six ADX-TPTX rats, except at the third hour of HCl loading, at which there remained only two ADX-TPTX rats. Pi, inorganic phosphorus. ${ }^{*} P<0.05$ or less vs. control period in the same group. ${ }^{\ddagger} P<0.05$ or less vs. intact rats at the same period. ${ }^{\S} P<0.05$ or less vs. ADX rats at the same period.

noassay (19). Also, values ranging from 1.0 to $15.5 \mathrm{pg} / \mathrm{ml}$ for circulating PTH concentration were found in normal humans using a sensitive cytochemical bioassay (33). Thus the normal circulating PTH level in humans and rats is in the $10^{-12}-10^{-11}$ $M$ range. In addition, significant decreases in serum iPTH concentration after calcium infusion were detected in the pres- 
Table V. GFR and Urinary Excretion Rates in ADX HCl-loaded Rats (Groups VIII-X)

\begin{tabular}{|c|c|c|c|c|}
\hline & \multirow[b]{2}{*}{ Control period } & \multicolumn{3}{|c|}{ HCl loading (min) } \\
\hline & & $0-60$ & $60-120$ & $120-180$ \\
\hline \multicolumn{5}{|l|}{ GFR, $\mathrm{ml} / \mathrm{min}$} \\
\hline Intact & $1.04 \pm 0.04$ & $0.93 \pm 0.03^{*}$ & $0.81 \pm 0.03^{*}$ & $0.82 \pm 0.04^{*}$ \\
\hline $\mathrm{ADX}$ & $0.67 \pm 0.03^{\ddagger}$ & $0.61 \pm 0.04^{* \ddagger}$ & $0.52 \pm 0.05^{* \ddagger}$ & $0.53 \pm 0.01^{* \ddagger}$ \\
\hline ADX-TPTX & $0.71 \pm 0.06^{\ddagger}$ & $0.60 \pm 0.06^{* \pm}$ & $0.52 \pm 0.07^{* \pm}$ & $0.53 \pm 0.01^{* \ddagger}$ \\
\hline \multicolumn{5}{|c|}{ Urine flow rate, $\mu \mathrm{l} / \mathrm{min}$} \\
\hline Intact & $56 \pm 8$ & $48 \pm 11$ & $37 \pm 9$ & $41 \pm 10$ \\
\hline ADX & $35 \pm 4^{\ddagger}$ & $37 \pm 4$ & $36 \pm 2$ & $50 \pm 5$ \\
\hline ADX-TPTX & $42 \pm 8$ & $30 \pm 6$ & $27 \pm 5$ & $19 \pm 2^{\S}$ \\
\hline \multicolumn{5}{|c|}{ Urine osmolality, mosmol/ $\mathrm{kg} \mathrm{H}_{2} \mathrm{O}$} \\
\hline Intact & $370 \pm 46$ & $382 \pm 65$ & $505 \pm 133$ & $406 \pm 55$ \\
\hline ADX & $359 \pm 13$ & $389 \pm 14$ & $388 \pm 12$ & $327 \pm 22$ \\
\hline ADX-TPTX & $376 \pm 46$ & $404 \pm 38$ & $409 \pm 63$ & $532 \pm 67$ \\
\hline \multicolumn{5}{|l|}{ Urine pH } \\
\hline Intact & $5.98 \pm 0.11$ & $6.03 \pm 0.13$ & $5.88 \pm 0.16$ & $5.72 \pm 0.16^{*}$ \\
\hline ADX & $5.64 \pm 0.17$ & $5.51 \pm 0.15^{\ddagger}$ & $5.39 \pm 0.18^{\ddagger}$ & $5.41 \pm 0.13$ \\
\hline ADX-TPTX & $5.82 \pm 0.30$ & $5.77 \pm 0.20$ & $5.67 \pm 0.20$ & $5.60 \pm 0.20$ \\
\hline \multicolumn{5}{|c|}{$(\mathrm{UV}) \mathrm{HCO}_{3}, \mathrm{nmol} / \mathrm{min}$} \\
\hline Intact & $48 \pm 18$ & $45 \pm 17$ & $27 \pm 12^{*}$ & $21 \pm 14^{*}$ \\
\hline ADX & $17 \pm 9$ & $8 \pm 3^{*}$ & $7 \pm 4^{*}$ & $8 \pm 6^{*}$ \\
\hline ADX-TPTX & $38 \pm 23$ & $17 \pm 9$ & $11 \pm 6^{*}$ & $3 \pm 1^{*}$ \\
\hline \multicolumn{5}{|c|}{ (UV)Na, $\mathrm{nmol} / \mathrm{min}$} \\
\hline Intact & $6,003 \pm 1,191$ & $4,534 \pm 881$ & $3,773 \pm 889^{*}$ & $4,437 \pm 909^{*}$ \\
\hline ADX & $4,365 \pm 631$ & $4,449 \pm 543$ & $4,429 \pm 231$ & $4,905 \pm 217$ \\
\hline ADX-TPTX & $4,892 \pm 631$ & $3,304 \pm 422^{*}$ & $2,778 \pm 390^{*}$ & $2,227 \pm 420^{*}$ \\
\hline \multicolumn{5}{|c|}{ (UV)Cl, $\mathrm{nmol} / \mathrm{min}$} \\
\hline Intact & $7,243 \pm 1,035$ & $5,753 \pm 810$ & $5,263 \pm 930$ & $5,983 \pm 1,101$ \\
\hline ADX & $5,341 \pm 573$ & $5,636 \pm 630$ & $5,881 \pm 269$ & $6,287 \pm 232$ \\
\hline ADX-TPTX & $5,863 \pm 702$ & $4,333 \pm 426^{*}$ & $3,784 \pm 274^{*}$ & $3,945 \pm 101^{*}$ \\
\hline \multicolumn{5}{|c|}{ (UV)K, nmol/min } \\
\hline Intact & $1,174 \pm 67$ & $922 \pm 35$ & $959 \pm 99$ & $1,275 \pm 193$ \\
\hline ADX & $480 \pm 56^{\ddagger}$ & $538 \pm 71^{\ddagger}$ & $747 \pm 102$ & $1,017 \pm 167^{*}$ \\
\hline ADX-TPTX & $484 \pm 53^{\ddagger}$ & $496 \pm 96^{\ddagger}$ & $593 \pm 131^{\ddagger}$ & $528 \pm 37^{\ddagger \S}$ \\
\hline \multicolumn{5}{|c|}{ (UV)Ca, $\mathrm{nmol} / \mathrm{min}$} \\
\hline Intact & $29 \pm 5$ & $31 \pm 5$ & $35 \pm 6$ & $37 \pm 8$ \\
\hline ADX & $6 \pm 2^{\ddagger}$ & $10 \pm 2$ & $15 \pm 5$ & $21 \pm 12^{*}$ \\
\hline ADX-TPTX & $34 \pm 12^{\S}$ & $31 \pm 16$ & $43 \pm 19^{\S}$ & $77 \pm 9^{* \neq \S}$ \\
\hline \multicolumn{5}{|c|}{ (UV)Mg, $\mathrm{nmol} / \mathrm{min}$} \\
\hline Intact & $158 \pm 22$ & $151 \pm 13$ & $124 \pm 24$ & $136 \pm 31$ \\
\hline ADX & $88 \pm 8^{\ddagger}$ & $86 \pm 8^{\ddagger}$ & $91 \pm 10$ & $95 \pm 15$ \\
\hline ADX-TPTX & $120 \pm 8$ & $91 \pm 10^{\ddagger}$ & $91 \pm 15$ & $100 \pm 6$ \\
\hline
\end{tabular}

Values are means \pm SE. See Table IV for definitions of groups and comparisons.

ent work. Moreover, high and low serum iPTH concentrations in acidotic and calcium-infused rats, respectively, were associated with high and low NcAMP values. Thus acute metabolic acidosis increased the level of circulating biologically active PTH in rats in this study. From the data obtained in experiments designed to analyze the renal response to acute acid loading, it is apparent that PTH contributed to augmentation of urinary net acid excretion. First, PTX as compared with intact rats had a marked defect in urinary acidification and net acid excretion during both control and acidosis periods. Second, the reduced various components of urinary net acid excretion in PTX rats were restored in a dose-dependent manner by infusion of hPTH-(1-34) in these animals (Figs. 4 and 5). Although different absolute values of urinary net acid excretion were obviously dependent on different levels of circulating PTH activity, a major difference in the evolution of the various components of urinary net acid excretion in response to $\mathrm{HCl}$ loading could not be demonstrated between PTX rats, intact rats in which circulating PTH increased, and PTX rats infused with hPTH-(1-34) at constant rates; this could have been due at least in part to the presence of different and varying adrenal hormone circulating levels in the latter various groups of rats that had different degrees of acidosis. Indeed, third, acidosis-induced significant increases in urinary 

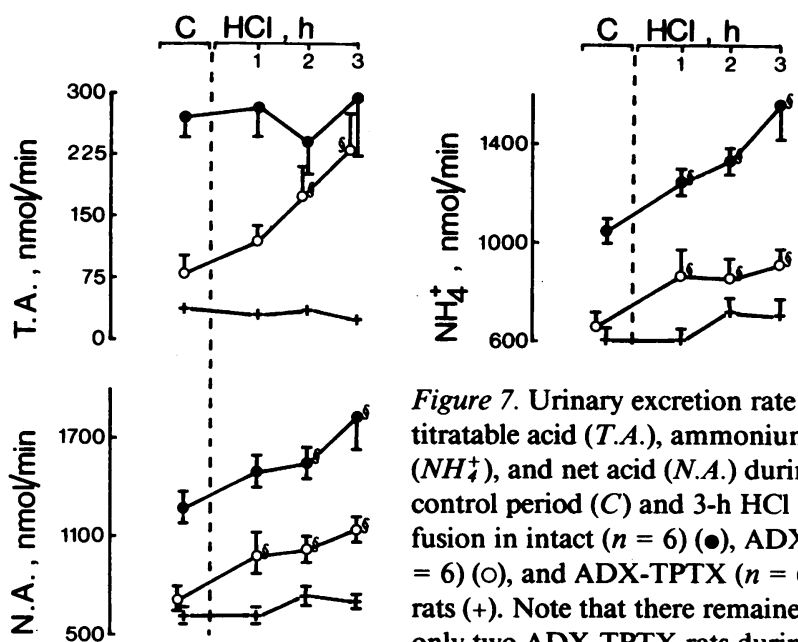

Figure 7. Urinary excretion rate of titratable acid (T.A.), ammonium $\left(N_{4}^{+}\right)$, and net acid (N.A.) during control period $(C)$ and 3-h $\mathrm{HCl}$ infusion in intact $(n=6)(\bullet), \operatorname{ADX}(n$ $=6)(0)$, and ADX-TPTX $(n=6)$ rats $(+)$. Note that there remained only two ADX-TPTX rats during

the third hour of $\mathrm{HCl}$ infusion. Points are means \pm SE $\$, P<0.05$ or less compared with control period.

phosphate (and thus titratable acid) fractional excretion, and in urinary ammonium and net acid excretion occurred in ADX but not in ADX-TPTX rats after $3 \mathrm{~h}$ of acid loading (Figs. 6 and 7). These observations strongly suggest that the acidosis-induced increase in the circulating PTH activity acted on the kidney to increase urinary net acid excretion.

An increase in circulating PTH concentration is expected to enhance urinary phosphate excretion due to inhibition of phosphate absorption by the proximal tubule. Indeed, urinary phosphate excretion was almost zero in PTX rats and was restored in a dose-dependent manner by hPTH-(1-34) infusion in these animals during both basal and acidosis states. In addition, an acidosis-induced increase in urinary phosphate fractional excretion was observed in intact and ADX, but not in PTX and ADX-TPTX rats. It is important to emphasize that an increased delivery of phosphate to distal parts of the nephron serves not only to enhance per se titratable acid excretion, but also to strongly stimulate the rate of proton secretion in collecting ducts, as has been previously demonstrated in our laboratory $(1,3)$. The latter event acts to decrease the urinary $\mathrm{pH}$ despite an increase in the urinary buffer content, which enhances titratable acid excretion all the more and favors ammonium excretion. It must be pointed out that the urinary $\mathrm{pH}$ was significantly higher in PTX than in intact or hPTH-(1-34)-infused PTX rats (Table III) and tended to be higher in ADX-TPTX than in ADX rats in the present study (Table V) despite a more profound degree of acidosis and a lesser urinary buffer content in the former animals. This must have resulted from a defect in collecting duct proton secretion in PTX and ADX-TPTX rats. Based on our previous observations $(1,3,9)$, we believe that PTX rats have a rate defect in collecting duct proton secretion because of the near complete absence of phosphate within the distal tubular fluid in these animals; note, however, that the localization and the cellular mechanism of the effect of luminal phosphate on proton secretion at collecting duct sites need to be established by further direct evaluation. Thus the metabolic acidosis-induced phosphaturia results, at least in part, from augmented PTH activity. In agreement with our results, an acute metabolic acidosis of 3-h duration in TPTX rats was found to be associated with no decrease in the sodium-dependent phosphate uptake by renal brush-border membrane vesicles (34). Also, acute metabolic acidosis after a 90 -min infusion of either $\mathrm{HCl}$ or ammonium chloride in acutely TPTX rats did not modify urinary phosphate excretion or phosphate absorption by the proximal convoluted tubule microperfused in vivo (35). However, in another study in chronically PTX rats, a 3-h infusion of ammonium chloride resulted in a significant increase in the urinary phosphate fractional excretion, which was attributed to acidemia-related undefined factors other than PTH (36).

A PTH-induced increase in the proximal ammonia production may seem less expected, but is possible for the following reasons. We have previously observed that PTH administration in TPTX rats enhances urinary ammonium excretion in every animal (1). In the present work, the urinary ammonium excretion rate was significantly reduced in PTX rats and restored in a dose-dependent manner by hPTH-(1-34) infusion in these animals (Fig. 5), which could hardly be explained only by differences in the urinary pH (see Table III). Also, an acidosis-induced significant increase in urinary ammonium excretion occurred in ADX rats as rapidly as during the first hour of $\mathrm{HCl}$ infusion, but not in ADX-TPTX animals despite similar decreases in the urinary $\mathrm{pH}$. Among the known proximal cellular responses to PTH is the stimulation of gluconeogenesis, which may be metabolically associated with stimulation of ammoniagenesis (37); in fact, PTH has recently been shown to stimulate the cellular ammonia production in suspensions of canine proximal tubular fragments (38). Thus we suggest that PTH also acts to increase renal ammonia production and excretion in response to metabolic acidosis. The latter contention is also supported by the fact that Good and Burg (39) have observed that renal ammonia production, which occurs in all portions of the nephron, increases after metabolic acidosis only in the $\mathrm{S} 1$ and $\mathrm{S} 2$ proximal segments, i.e., in PTH target sites. It is worth pointing out that acute metabolic acidosis per se exerted little net homeostatical renal effects in the absence of parathyroid and adrenal glands in this study. The urinary $\mathrm{pH}$ and bicarbonate excretion rate did decrease during acidosis in ADX-TPTX rats, but this was of little importance in enhancing net acid excretion in the absence of hormonemediated phosphate and ammonium renal response. Nevertheless, it must be recognized that further work is needed to directly demonstrate whether PTH actually increases the secretion of ammonia within the proximal tubular fluid.

In addition to exerting renal effects, PTH may also contribute to the defense against metabolic acidosis by exerting extrarenal actions. A high rate of mortality after acid loading was observed in PTX animals in this and previous $(23,24)$ studies. Wachman and Bernstein (40) have reported in normal humans that chronic ammonium chloride loading was associated with negative calcium balance, together with a rise in urinary hydroxyproline levels, phosphate renal clearance, and excretion rate; also, plasma iPTH levels were elevated in two of four cases during metabolic acidosis (40). These observations led the authors (40) to hypothesize that increased PTH activity during metabolic acidosis may increase bone resorption to provide additional amount of buffer base in the extracellular medium and may increase renal phosphate clearance to augment urinary buffering capacity and acid excretion. A similar hypothesis has also been expressed by Wills (41). Consistent 
with the latter hypothesis, several studies $(23,24,42)$, although not all (43), have shown that PTH is necessary for the optimal body buffering of acute acid loads in nephrectomized rats and dogs, probably by increasing bone buffering. Also, in some experimental models of chronic PTH administration in dogs, an extrarenal alkali input into the extracellular fluid compartment, probably from bone, was shown to contribute to the PTH-induced metabolic alkalosis $(6,7)$.

Thus circulating PTH activity is enhanced by an acute acid load and PTH in turn acts on kidney as described above, and possibly on bone, to contribute to the defense against metabolic acidosis, which may constitute a homeostatic response of the parathyroid glands to acute metabolic acidosis. Elevated circulating iPTH activities during acute metabolic acidosis had previously been observed in only one study in humans (45). Whether chronic metabolic acidosis is associated with sustained increased PTH activity is uncertain because either elevated $(40,45)$ or unchanged $(40,44,46)$ serum iPTH concentrations were reported during chronic metabolic acidosis in humans. As already discussed above, we therefore suggest that both PTH, at least during acute metabolic acidosis, and adrenal hormones, perhaps particularly in a chronic setting, mediate at least in part the renal responses against metabolic acidosis and thus appear to coordinately regulate the various components of urine acidification in proximal and distal parts of the nephron, which leads to the concept of a pluri-hormonal control of acid-base balance (47). It is worth noting that PTH was recently shown to stimulate corticosteroid secretion by adrenal glomerulosa cells in vitro $(48,49)$. The mechanism by which acute metabolic acidosis may stimulate endogenous PTH secretion is unknown. In a previous study on dispersed bovine parathyroid cells, lowering the $\mathrm{pH}$ of the ambient medium decreased the release of PTH that was previously maximally stimulated by a low extracellular calcium concentration, but possible effects of extracellular $\mathrm{pH}$ or bicarbonate concentration on basal PTH secretion were not tested (50). More recently, PTH secretion by parathyroid cells in vitro has been shown to be modulated by CAMP- and protein kinase C-mediated cell activation by various secretagogues (reviewed in reference 51).

\section{Acknowledgments}

We thank Mrs. Chantal Nicolas for valuable secretarial assistance and Mr. Eric Marty for technical assistance.

This study was supported by grants from the Institut National de la Santé et de la Recherche Médicale (CRE 865003), the Université Paris 6, and the Fondation pour la Recherche Médicale Française.

\section{References}

1. Bichara, M., O. Mercier, M. Paillard, and F. Leviel. 1986. Effects of parathyroid hormone on urinary acidification. Am. J. Physiol. 251 (Renal Fluid Electrolyte Physiol. 20):F444-F453.

2. Bank, N., and H. S. Aynedjian. 1976. A micropuncture study of the effect of parathyroid hormone on renal bicarbonate reabsorption. J. Clin. Invest. 58:336-344.

3. Mercier, O., M. Bichara, M. Paillard, and A. Prigent. 1986. Effects of parathyroid hormone and urinary phosphate on collecting duct hydrogen secretion. Am. J. Physiol. 251 (Renal Fluid Electrolyte Physiol. 20):F802-F809.
4. Hulter, H. N., and J. C. Peterson. 1985. Acid-base homeostasis during chronic PTH excess in humans. Kidney Int. 28:187-192.

5. Licht, J. H., and K. McVicker. 1982. Parathyroid-hormone-induced metabolic alkalosis in dogs. Miner. Electrolyte Metab. 8:78-91.

6. Hulter, H. N., A. Sebastian, R. D. Toto, E. L. Bonner, Jr., and L. P. Ilnicki. 1982. Renal and systemic acid-base effects of the chronic administration of hypercalcemia-producing agents: calcitriol, PTH, and intravenous calcium. Kidney Int. 21:445-458.

7. Hulter, H. N., R. D. Toto, L. P. Ilnicki, B. Halloran, and A. Sebastian. 1983. Metabolic alkalosis in models of primary and secondary hyperparathyroid states. Am. J. Physiol. 245 (Renal Fluid Electrolyte Physiol. 14):F450-F461.

8. Mitnick, P., A. Greenberg, T. Coffman, E. Kelepouris, C. J. Wolf, and S. Goldfarb. 1982. Effects of two models of hypercalcemia on renal acid base metabolism. Kidney Int. 21:613-620.

9. Houillier, P., A. Prigent, P. Borensztein, M. Bichara, and M. Paillard. 1988. Chronic neutral phosphate infusion induces sustained renal metabolic alkalosis. Kidney Int. 33:401. (Abstr.)

10. Mercier, O., A. Prigent, M. Bichara, M. Paillard, and F. Leviel. 1986. Effects of increase in plasma calcium concentration on renal handling of $\mathrm{NaCl}$ and $\mathrm{NaHCO}_{3}$. Am. J. Physiol. 250 (Renal Fluid Electrolyte Physiol. 19):F441-F450.

11. Heinemann, H. O. 1965. Metabolic alkalosis in patients with hypercalcemia. Metab. Clin. Exp. 14:1137-1152.

12. Bichara, M., O. Mercier, P. Houillier, M. Paillard, and F. Leviel. 1987. Effects of antidiuretic hormone on urinary acidification and on tubular handling of bicarbonate in the rat. J. Clin. Invest. 80:621630.

13. Bichara, M., M. Paillard, B. Corman, C. de Rouffignac, and F. Leviel. 1984. Volume expansion modulates $\mathrm{NaHCO}_{3}$ and $\mathrm{NaCl}$ transport in the proximal tubule and Henle's loop. Am. J. Physiol. 247 (Renal Fluid Electrolyte Physiol. 16):F140-F150.

14. Welbourne, T. C. 1976. Acidosis activation of the pituitary-adrenal-renal glutaminase I axis. Endocrinology. 99:1071-1079.

15. Perez, G. O., J. R. Oster, C. A. Vaamonde, and F. H. Katz. 1977. Effect of $\mathrm{NH}_{4} \mathrm{Cl}$ on plasma aldosterone, cortisol and renin activity in supine man. J. Clin. Endocrinol. \& Metab. 45:762-767.

16. Perez, G. O., J. R. Oster, F. H. Katz, and C. A. Vaamonde. 1979. The effect of acute metabolic acidosis on plasma cortisol, renin activity and aldosterone. Horm. Res. (Basel). 11:12-21.

17. Dubrovsky, A. H. E., R. C. Nair, M. K. Byers, and D. Z. Levine. 1981. Renal net acid excretion in the adrenalectomized rat. Kidney Int. 19:516-528.

18. Schambelan, M., A. Sebastian, B. A. Katuna, and E. Arteaga. 1987. Adrenocortical hormone secretory response to chronic $\mathrm{NH}_{4} \mathrm{Cl}$ induced metabolic acidosis. Am. J. Physiol. 252 (Endocrinol. Metab. 15):E454-E460.

19. Toverud, S. U., A. Boass, S. C. Garner, and D. B. Endres. 1986. Circulating parathyroid hormone concentrations in normal and vitamin D-deprived rat pups determined with an $\mathrm{N}$-terminal-specific radioimmunoassay. Bone Miner. 1:145-155.

20. Sutton, R. A. L., and J. H. Dirks. 1981. Renal handling of calcium, phosphate, and magnesium. In The Kidney. B. M. Brenner and F. C. Rector, Jr., editors. 2nd ed. W. B. Saunders Company, Philadelphia. 551-618.

21. Broadus, A. E., J. E. Mahaffey, F. C. Bartter, and R. M. Neer 1977. Nephrogenous cyclic adenosine monophosphate as a parathyroid function test. J. Clin. Invest. 60:771-783.

22. Mercier, O., M. Bichara, M. Paillard, J. P. Gardin, and F. Leviel. 1985. Parathyroid hormone contributes to volume expansioninduced inhibition of proximal reabsorption. Am. J. Physiol. 248 (Renal Fluid Electrolyte Physiol. 17):F100-F103.

23. Fraley, D. S., and S. Adler. 1979. An extrarenal role for parathyroid hormone in the disposal of acute acid loads in rats and dogs. $J$. Clin. Invest. 63:985-997.

24. Arruda, J. A. L., V. Alla, H. Rubinstein, M. Cruz-Soto, S. Sabatini, D. C. Batlle, and N. A. Kurtzman. 1980. Parathyroid hor- 
mone and extrarenal acid buffering. Am. J. Physiol. 239 (Renal Fluid Electrolyte Physiol. 8):F533-F538.

25. Batlle, D. C., and N. A. Kurtzman. 1985. Renal regulation of acid-base homeostasis: integrated response. In The Kidney Physiology and Pathophysiology. D. W. Seldin and G. Giebisch, editors. Raven Press, Ltd., New York. 1539-1565.

26. Cogan, M. G., and F. C. Rector, Jr. 1986. Acid-base disorders. In The Kidney. B. M. Brenner and F. C. Rector, Jr., editors. 3rd ed. W. B. Saunders Company, Philadelphia. 457-517.

27. Hamm, L. L., and E. E. Simon. 1987. Roles and mechanisms of urinary buffer excretion. Am. J. Physiol. 253 (Renal Fluid Electrolyte Physiol. 22):F595-F605.

28. DuBose, T. D., Jr., and C. R. Caflisch. 1988. Effect of selective aldosterone deficiency on acidification in nephron segments of the rat inner medulla. J. Clin. Invest. 82:1624-1632.

29. Sartorius, O. W., D. Calhoon, and R. F. Pitts. 1953. Studies on the interrelationships of the adrenal cortex and renal ammonia excretion by the rat. Endocrinology. 52:256-265.

30. Wilcox, C. S., D. A. Cemerikic, and G. Giebisch. 1982. Differential effects of acute mineralo- and glucocorticosteroid administration on renal acid elimination. Kidney Int. 21:546-556.

31. Boross, M., J. Kinsella, L. Cheng, and B. Sacktor. 1986. Glucocorticoids and metabolic acidosis-induced renal transports of inorganic phosphate, calcium, and $\mathrm{NH}_{4}$. Am. J. Physiol. 250 (Renal Fluid Electrolyte Physiol. 19):F827-F833.

32. Welbourne, T. C., G. Givens, and S. Joshi. 1988. Renal ammoniagenic response to chronic acid loading: role of glucocorticoids. Am. J. Physiol. 254 (Renal Fluid Electrolyte Physiol. 23):F134-F138.

33. Chambers, D. J., J. Dunham, J. M. Zanelli, J. A. Parsons, L. Bitensky, and J. Chayen. 1978. A sensitive bioassay of parathyroid hormone in plasma. Clin. Endocrinol. 9:375-379.

34. Levine, B. S., J. A. Kraut, D. R. Mishler, and P. W. Crooks. 1986. Effect of acute acidemia on phosphate uptake by renal proximal tubular brush-border membranes. Am. J. Physiol. 251 (Renal Fluid Electrolyte Physiol. 20):F889-F896.

35. Quamme, G. A. 1985. Effects of metabolic acidosis, alkalosis, and dietary hydrogen ion intake on phosphate transport in the proximal convoluted tubule. Am. J. Physiol. 249 (Renal Fluid Electrolyte Physiol. 18):F769-F779.

36. Guntupalli, J., B. Eby, and K. Lau. 1982. Mechanisms for the phosphaturia of $\mathrm{NH}_{4} \mathrm{Cl}$ : dependence on acidemia, but not on diet $\mathrm{PO}_{4}$ or PTH. Am. J. Physiol. 242 (Renal Fluid Electrolyte Physiol. 11):F552-F560.

37. Tannen, R. L. 1978. Ammonia metabolism. Am. J. Physiol. 235 (Renal Fluid Electrolyte Physiol. 4):F265-F277.

38. Chobanian, M. C., and M. R. Hammerman. 1988. Parathyroid hormone stimulates ammoniagenesis in canine renal proximal tubular segments. Am. J. Physiol. 255 (Renal Fluid Electrolyte Physiol. 24):F847-F852.

39. Good, D. W., and M. B. Burg. 1984. Ammonia production by individual segments of the rat nephron. J. Clin. Invest. 73:602-610.

40. Wachman, A., and D. S. Bernstein. 1970. Parathyroid hormone in metabolic acidosis: its role in pH homeostasis. Clin. Orthop. Relat. Res. 69:252-263.

41. Wills, M. R. 1970. Fundamental physiological role of parathyroid hormone in acid-base homoeostasis. Lancet. ii:802-804.

42. Arruda, J. A. L., V. Alla, G. Rubinstein, M. Cruz-Soto, S. Sabatini, D. C. Batlle, and N. A. Kurtzman. 1982. Metabolic and hormonal factors influencing extrarenal buffering of an acute acid load. Miner. Electrolyte Metab. 8:36-43.

43. Madias, N. E., C. A. Johns, and S. M. Homer. 1982. Independence of the acute acid-buffering response from endogenous parathyroid hormone. Am. J. Physiol. 243 (Renal Fluid Electrolyte Physiol. 12):F141-F149.

44. Weber, H. P., R. W. Gray, J. H. Dominguez, and J. Lemann, Jr. 1976. The lack of effect of chronic metabolic acidosis on 25-OH-vitamin D metabolism and serum parathyroid hormone in humans. $J$. Clin. Endocrinol. \& Metab. 43:1047-1055.

45. Coe, F. L., J. S. Firpo, Jr., D. L. Hollandsworth, L. Segil, J. M. Canterbury, and E. Reiss. 1975. Effect of acute and chronic metabolic acidosis on serum immunoreactive parathyroid hormone in man. Kidney Int. 8:262-273.

46. Bushinsky, D. A., M. J. Favus, A. B. Schneider, P. K. Sen, L. M. Sherwood, and F. L. Coe. 1982. Effects of metabolic acidosis on PTH and $1,25(\mathrm{OH})_{2} \mathrm{D}_{3}$ response to low calcium diet. Am. J. Physiol. 243 (Renal Fluid Electrolyte Physiol. 12):F570-F575.

47. Paillard, M., and M. Bichara. 1989. Peptide hormone effects on urinary acidification and acid-base balance: $\mathrm{PTH}, \mathrm{ADH}$, and glucagon. Am. J. Physiol. 256 (Renal Fluid Electrolyte Physiol. 25):F973F985.

48. Isales, C. M., P. Q. Barrett, M. L. Brines, W. B. Bollag, and H. Rasmussen. 1989. Parathyroid hormone (PTH) modulates AII-stimulated aldosterone secretion. Kidney Int. 35:300. (Abstr.)

49. Rosenberg, J., M. Pines, J. J. Levy, R. F. Nutt, M. P. Caulfield, J. Russell, L. M. Sherwood, and S. Hurwitz. 1989. Renal and adrenal adenosine $3^{\prime}, 5^{\prime}$-monophosphate production and corticosteroid secretion in response to synthetic chicken parathyroid hormone-(1-34). Endocrinology. 125:1082-1089.

50. Brown, E. M., C. J. Pazoles, C. E. Creutz, G. D. Aurbach, and H. B. Pollard. 1978. Role of anions in parathyroid hormone release from dispersed bovine parathyroid cells. Proc. Natl. Acad. Sci. USA. 75:876-880

51. Morrissey, J. J. 1988. Effect of phorbol myristate acetate on secretion of parathyroid hormone. Am. J. Physiol. 254 (Endocrinol. Metab. 17):E63-E70. 